\title{
Yeni Bir Belgeye Göre XVI. Yüzyılın İlk Yarısında Osmanlı Mülâzemet Sistemi
}

\author{
Ercan Alan*
}

Ottoman Mulâzamat System in the First Half of the $16^{\text {th }}$ Century in the Light of a New Document

Abstract $\square$ Mulazemet was a prerequisite for joining the Ottoman ilmiye establishment. This paper is a study of a mulazemet register dated 906-911 Hijri (15011506), the earliest mulazemet register found so far. It shows that the mulazemet system gained its shape and form in the reign of Bayezid II. Although it is known that mulazemet system was in use since the end of the $15^{\text {th }}$ century, how it was applied has remained obscure. It is generally accepted that mulazemet system was systematized by Ebussuud Efendi in the second half of $16^{\text {th }}$ century during the reign of Suleiman the Magnificent. Beginning with İsmail Hakkı Uzunçarşılı, several researchers have studied different aspects of the issue, still, the development of the mulazemet system has remained in the dark. A detailed analysis of this register shows that mulazemet was already a systematized practice during the reign of Bayezid II.

Keywords: Bayezid II, Ilmiye, Kadiasker of Rumelia, Ruznamce register, Qadâ, Qâdi, Madrasa, Mudarris, Mulazemet, $16^{\text {th }}$ century.

Daha çok, ilmiye mesleğindeki intisap süreçlerini ve mesleki kariyere başlangıç aşamalarını ifade eden bir terim olarak mülâzemet medrese mezunlarının müderris ya da kadı olmak için isimlerinin deftere kaydedilmesiyle başlayan kadı veya müderrislik adaylığı süreci ile fiili olarak kadı ve müderrislik yaparken "müddet-i örfiye” olarak da adlandırılan muayyen görev sürelerini dolduran kadı

* Bitlis Eren Üniversitesi 
ve müderrislerin yeni bir göreve atanıncaya kadar İstanbul'da geçirdikleri mazuliyet ve mesleki gelişim/eğitim sürecini ifade etmektedir.

Osmanlı ilmiye teşkilatını inceleyen çalışmalarda mülâzemet sisteminin ortaya çıkışı ilgili farklı görüşler ileri sürülse de bu husus dönemin belgelerine dayalı olarak tartışılmış değildir. Uzunçarşılı'dan İnalcık'a kadar konu üzerinde araştırma yapmış olan tarihçiler bu konuda ya bir fikir beyan etmemiş ya da bazı ipuçlarından hareketle sistemin ortaya çıkışı hakkında çeşitli tahminlerde bulunmuşlardır. Osmanlı mülâzemet sistemi hakkındaki ilk bilgiler, İsmail Hakkı Uzunçarşılı’nın araştırmasına dayanmaktadır. Fakat Uzunçarşılı, eserinde mülâzemet usulünün ortaya çıkışı ile ilgili bir tartışmaya girmemiş ve mülâzemet usulünün Ebussuud Efendi’nin Kanuni döneminde yaptığı düzenlemeyle sistemleştirildiğini ifade etmiştir. ${ }^{1}$ Halil İnalcık, kadılık sistemini incelediği bir makalesinde, Mustafa Cezar tarafından yayınlanan bir belgeye atfen mülâzemet sisteminin Ebussuud Efendi'nin düzenlemelerinden önce de mevcut olduğunu ileri sürmüştür. ${ }^{2}$ Mehmet İpşirli, Osmanlı Devleti’nde Kazaskerlik (XVII. Yüzyıla Kadar) başlıklı doçentlik çalışmasında sistemin ortaya çıkışı ve mülâzım verme usullerini ayrıntılı olarak incelemiş fakat sistemin ortaya çıkışıyla ilgili bir yorumda bulunmamıştır. ${ }^{3}$ Mülâzemet hakkındaki son araştırmalardan birisi de Yasemin Beyazıt'a aittir. ${ }^{4}$ Beyazıt, Fatih Kanunnamesi'ne istinaden XV. yüzyılın son çeyreğinden

1 İsmail Hakkı Uzunçarşıll, Devleti’nin İlmiye Teşkilatı (Ankara: Türk Tarih Kurumu 1984), s. 45-53.

2 Halil İnalcık, "Kazasker Ruznamçe Defterine Göre Kadılık", Adalet Kitabı (Ankara: T.C. Adalet Bakanlığı, 2007), s. 127-132. Mustafa Cezar, Osmanlı Taribinde Levendler (İstanbul: İstanbul Güzel Sanatlar Akademisi Yayınları, 1965), s. 375-378.

3 Mehmet İpşirli, “Osmanlı Devleti’nde Kazaskerlik (XVII. Yüzyıla Kadar)”, (Doçentlik Tezi), İstanbul Üniversitesi, 1982. İpşirli' nin bu çalışmasının yayımlanmış hali için bkz. "Osmanlı Devleti'nde Kazaskerlik (XVII. Yüzylla kadar)" Belleten, LXI (1997), s. 597699. Mehmet İpşirli ruznamçe defterlerinin en eskisi olarak bu makalede incelenen deftere işaret etmiş fakat defter ve sistemin teşekkülü hakkında bir yorumda bulunmamıştır: "Bu defterlerin en azından XVI. yüzyıl başlarından itibaren tutulduğunu ve devamlı gelişerek düzenli bir şekil aldığını söylemek mümkündür. XVI. yüzyıl başlarına ait sadece mülâzemet kayıtlarını ihtiva eden bir defter bulunmaktadır (TSMA, nr. D. 5605/1-2)." Mehmet İpşirli, "Kazasker", Türkiye Diyanet Vakfi İlâm Ansiklopedisi (DİA), 25, s. 143-144.

4 Yasemin Beyazıt, Osmanl İlmiye Mesleğinde İstihdam (Ankara: Türk Tarih Kurumu Yayınları, 2014), s. 31-32. Ayrıca bkz. Yasemin Beyazıt, "Osmanlı İlmiye Bürokrasisinde Şeyhülislamlığın Değişen Rolü ve Mülazemet Sistemi (XVI.-XVIII. Yüzyıllar)”, Belleten, CLXXIII(2009), s. 423-441. 
itibaren mesleğe giriş mekanizmasına mülâzemet sisteminin getirildiğini söyler. Beyazıt ayrıca Mecdi'nin Hadaiku's-Şakaik adlı eserindeki kayıtları inceleyerek I. Selim döneminde mülâzemet uygulamasının yürürlükte olduğunu göstermiştir.

Osmanlı belgelerinde mülâzemet ve mülâzım tabirleri ilk olarak Fatih Kanunnamesi'nde geçmektedir. Kanunnamenin, "Bâb-1 Evvel Merâtib-i A'yân ü Ekâbir Beyânındadur” başlı̆̆ı altında ilmiye mesleğiyle ilgili düzenlemelere yer verilirken mülâzımlar hakkında "Ve ibtidâ yeni mülâzım yirmi akça medreseye, andan yirmi beş, andan otuz, andan otuz beş, andan kırk, andan kırk beş, andan elli akçaya vâsıl olurlar. Elli akça müderris cümle ağaların üstüne oturur. Sahn'a vardukdan sonra beşyüz akça kadı olup, andan kadı́asker olurlar." ${ }^{5}$ ifadesi yer almaktadır. Bu ifadelerden ilmiye mesleğindeki mülâzemet uygulamasının Fatih döneminden itibaren var olduğunu anlamaktayız, ancak uygulamanın sistematik olarak yürütüldüğüne dair bu döneme ait herhangi bir belge tespit edilememiştir.

Osmanlı ilmiye sınıfına has bir uygulama olarak başlangıcını Fatih dönemine bağlayabileceğimiz mülâzemet sistemi, Kanuni döneminde Ebussuud Efendi tarafından sistemleştirilmiştir. XVI. yüzyılın ortalarına doğru ilmiye sistemine girişte yaşanan sıkıntıları gidermek ve kanunlara aykırı bir şekilde ilmiye mesleğine girmek isteyenleri engellemek için Kanuni Sultan Süleyman 944 (1538) tarihinde çıkardığı bir fermanla dönemin Rumeli kadıaskeri Ebussuud Efendi'yi mülâzemet sistemini düzenlemekle görevlendirmişti. Ebussuud ise yaptığı düzenleme ile ulemanın payesine göre belli sayıda mülâzım vermesini ve bu kişilerin ayrı bir deftere kaydedilmesini ve her yedi yılda bir nevbetin uygulanmasını kanunlaştırmıştır. ${ }^{6}$ Burada Ebussuud'un getirdiği yenilik mesleğe yeni giren mülâzımlar için ayrı bir defter tutulması ve hangi derecedeki ulemanın ne kadar mülâzım vereceğinin bir düzene konulmasıdır.

Ebussuud Efendi'nin yaptığı düzenlemenin en önemli sonuçlarından birisi, ilmiye mesleğine yeni girecek mülâzımlar için ayrı bir defter (ruznamçe)

5 Fatih Sultan Mehmed, Atam Dedem Kanunu Kanunnâme-i Âl-i Osman, haz. Abdülkadir Özcan (İstanbul: Yitik Hazine Yayınları, 2013), s. 11.

6 Nev'îzâde Atai, Hadâiküll-Hakâik fî Tekmiletü̧ş-Şakâik, haz. Abdülkadir Özcan (İstanbul: Çağrı Yayınları, 1989), s. 184, Alper Yıldırım, "Müstakim-zade Süleyman Saadeddin'in Devhatü'l-Meşayih, Osmanlı Şeyhülislamlarının Biyografileri Adlı Eserinin Transkripsiyon ve Değerlendirmesi”, (Yüksek Lisans Tezi), Mustafa Kemal Üniversitesi, Sosyal Bilimler Enstitüsü, 2014, s. 118, ayrıca Hezarfen Hüseyin Efendi, Telhîsüll-Beyân Fî Kavânîn-i Âl-i Osmân, haz. Sevim İlgürel (Ankara: Türk Tarih Kurumu, 1998), s. 203. 
tutulmaya başlanmış olmasıdır. ${ }^{7}$ Ebussuud'dan sonra tutulan bütün mülâzemet defterlerinde sadece mesleğe yeni giren mülâzımlar kaydedilmektedir. Ancak bir medrese ya da kazadan munfasıl olduktan sonra mülâzemette bulunan kadı ve müderrislerin kayıtlarının tutulduğu defterler ayrı bir seri teşkil etmekte olup bu ayrımın başlangıcı da Kanuni dönemidir. İlmiye mesleğine giriş niteliğindeki ilk mülâzemet kayıtları Rumeli kadıaskerliği tarafından tutulurken, bir kazadan ya da medreseden munfasıl olup İstanbul'a gelen kişilerin mülâzemet işleri ise eğer görev yeri Anadolu kazaskerliğine bağlı ise Anadolu kazaskerliği tarafından, Rumeli kazaskerliğine bağlı ise Rumeli kazaskeri tarafından yürütülür ve görevden ayrılma ve yeni göreve tayin işlemleri ruznamçe defterlerine kaydedilirdi.

Medreseden mezun olup ilmiye mesleğine girecek "yeni mülâzımların" işlerinin takibinden ve mülâzımların deftere kaydedilmesinden Rumeli kadıaskeri sorumlu idi. Bu durum hem dönemin yazarlarının eserlerinde hem de arşiv belgelerinde açıkça görülmektedir. III. Mehmet'in tahta çıkışından sonra 1004 (1595) tarihinde Rumeli kadıaskerine gönderilen bir fermanda mülâzım alınması için kendisinin görevlendirildiği yazmaktadır. ${ }^{8}$ Burada, mülâzemet işlerinin Rumeli kazaskerine havale edilmesinden bu işten sorumlu kişinin Rumeli kadıaskeri olduğu anlaşılmakta ve mülâzımların kaydedildiği defter hakkında "mülâzemet defteri” tabiri kullanılmaktadır. ${ }^{9}$ Mülâzemet kayıtlarını içeren ruznamçe defterlerinin tamamında Rumeli kadıaskerliği yapmış kişilerin mührünün bulunması mülâzemetten sorumlu kadıaskerlerin Rumeli kadıaskerleri olduğunu ayrıca teyid etmektedir.

Kanuni döneminden günümüze ulaşabilmiş ilk mülâzemet defteri 951-959 (1544-1556) tarihlidir. Bu makalenin konusunu teşkil eden defter ise, 951-959 (1544-1556) tarihli mülâzemet ruznamçesinden 43 yll önce düzenlenmiş olup mülâzemet sisteminin II. Bayezid dönemindeki durumunu ortaya koymaktadır.

7 Kanuni dönemi düzenlemelerini yansıtan ilk mülâzemet defteri 951-959 (1544-1556) tarihli olup sırasıyla Ebussuud, Çivizade Şeyh Muhyiddin Mehmed ve Bostan Efendi dönemlerine ait mülâzım kayıtlarını içermektedir.

8 Bu durum Gelibolulu Mustafa Âli tarafından "bir dânişmend mülâzım olup Rumili Kadıaskeri'nin defterine lâhık ...” şeklinde açıklanmaktadır. Gelibolulu Mustafa Âlî, Künhül-Ahbâr Fatih Sultan Mehmed Devri 1451-1481, haz. M. Hüdai Şentürk (Ankara: Türk Tarih Kurumu, 2003), II, s. 74. Ayrıca Hezârfen Hüseyin Efendi, Telhîsül-Beyân fî Kavânîn-i Âl-i Osmân, s. 202 ve Nimeti Efendi Kanunnamesi'nden nakille Uzunçarşılı, Ilmiye Teşkilatı, s. 48 bu bilgiyi teyid etmektedirler.

9 BOA, Mühimme Defteri, No: 73, hüküm: 740. 
Araştırmamıza konu olan defter, mülâzemet kayıtlarını içeren en eski tarihli defter olup Topkapı Sarayı Arşivi'nde 5065/1 numarada kayıtlıdır. 906-911 (15011506) tarihleri arasındaki kayıtları ihtiva eden defter 7 varaktan oluşmaktadır. Defter, yüzyıllar boyunca sürecek mülâzemet uygulamasının bilinen sistemli ilk örneğidir.

Defterdeki mülâzemet kayıtları altı bölüm başlı̆̆ı altında toplanmıştır. Birinci bölümde yeni mülâzımlar, ikinci bölümde Rumeli medreselerinden mazul mülâzımlar, üçüncü bölümde Rumeli kazalarından mazul mülâzım kadılar, dördüncü bölümde Anadolu medreselerinden mazul mülâzımlar, beşinci bölümde Anadolu kazalarından mazul kadılar altınca bölümde ise Acemler ve müteaccimler kayıtlıdır.

Bu defteri Kanuni dönemi mülâzemet defterlerinden farklı kılan en önemli husus hem mesleğe yeni giren mülâzımların hem de bir kaza ya da medreseden ayrıldıktan sonra yeni bir göreve atanana kadar mülâzemete devam eden ulemanın kayıtlarının aynı defterde tutulmuş olmasıdır. Defterde mesleğe yeni girenler için bu ilk mülâzemet dönemi zikredilirken "yeni mülâzımlar" tabiri kullanılmış, munfasıl kadı ve müderrisler için ise ayrı başlıklar açılmıştır. ${ }^{10}$ Bu sebeple Fatih Kanunnamesi'nde ve XVI. yüzyılın sonunda çıkarılan İlmiye Kanunnamesi'nde bahsi geçen "yeni mülâzım" tabirinin mesleğe yeni giren mülâzımları, munfasıl olup mülâzemete devam eden gruptan ayırmak için kullanıldığını söyleyebiliriz. Defterde yeni ve munfasıl mülâzımların kayıtlarının aynı defterde tutulmuş olması, Anadolu ve Rumeli kadıaskerlik daireleri arasında işlerin taksim ve yürütülmesi noktasında henüz bir ayrışmanın oluşmadığını düşündürmektedir.

Altı ayrı başlık altında düzenlenmiş olan defterin ilk bölümü "Tafsîl oldur ki mevâlî-yi müteveffâdan kalan ve gayrıdan mülâzım olup hâliyâ mevcûd olan yeni mülâzımları beyân ider." başlığını taşımaktadır. Başlıktan anlaşıldığına göre defterin bu bölümü kadı ve müderrislerden vefat edenlerle, görevinde terakki edenlerin verdikleri mülâzımlar için tutulmuştur. Defterdeki kayıtlar kronolojik bir sıra takip etmemektedir. Buradan anlaşılıyor ki bu mülâzemet defteri eldeki belgelerin derlenmesiyle sonradan oluşturulmuştur.

Defterin yeni mülâzımlara tahsis edilen bölümünde önce altı müderris ve kadının isimleri verilerek bunların vefatı dolayısıyla kalan talebelerden alınan yeni mülâzımlar kaydedilmiştir. Bu bölümün sonunda "Bu zikr olunan müteveffâ

10 TSMA, d. 5605/1. 
mevâlîden kalan cümle tâlib-i ilimler sene tis'a ve tis'a mie Muharreminin 10. gününde pâye-i serîr-i âlâya arz olunup mülâzemete kabûl olundular." notu düşülerek ilk bölüm tamamlanmıştır. 10 Muharrem 909 (5 Temmuz 1503) tarihinde Hâce, Kirmastili, Hatib-zâde, Yaralıca, Ahaveyn ve Efdal-zâde'nin vefatı dolayısıyla mülâzım kaydedilenlerin toplam sayısı 58 'dir. Hangi alimin vefatı dolayısıyla kaç talebesinin mülâzım alındığı aşağıda gösterilmiştir.

Hâce: 11

Kirmastili: 15

Hatib-zâde: 8

Yaralıca: 9

Ahaveyn: 7

Efdal-zâde: 8

Bu altı müderris ve kadıdan sonra "Ve merhûm Ali Çelebi el-Yegânînin fevtinden sonra beş mülâzım alındı. Bunlardır fî Muharrem sene 909” başlığı alında Ali Çelebi'nin vefatı dolayısıyla mülâzemete kaydedilen talebelerinin isimleri verilmektedir. Bu kaydı takiben "Merhûm Mevlânâ Arab tâlib-i ilimlerinden" başlı̆̆ altında iki kişinin mülâzemete kabul edildiği kaydedilmektedir. Buradan anlaşılıyor ki vefatları dolayısıyla kadı ve müderrislerin talebelerinden mülâzım alma yöntemi sistemin en başından beri uygulanmaktadır.

Bu kayıtları takiben Mevlânâ Emir ve Mevlânâ Muhyiddin'in verdikleri mülâzımlar kaydedilmiştir. Mevlânâ Emir, Amasya medresesine müderris olduğu için mülâzım vermiştir. Mevleviyet derecesindeki kadı ve müderrislerin ve büyük şehir müftülerinin göreve tayin, görev değişikliği ve sefere katılma gibi durumlarda verdikleri mülâzemet usulüne "teşrîfen mülâzemet" denilmektedir ve Mevlânâ Emir’in, Amasya medresesine müderris olduktan sonra mülâzım vermesi teşriften mülâzemetin de vefattan mülâzemette olduğu gibi bu dönemde mevcut olduğunu göstermektedir. Mevlânâ Muhyiddin ve Mevlânâ Müeyyed-zâde’nin hangi sebeple mülâzım verdikleri kaydedilmemiştir.

Bunlardan sonra "Sâbıkâ kadıasker olan Mevlânâ Alâaddîn"in mülâzımları kaydedilmiştir. Alaaddin’in mülâzımlarından Cemal Çelebi ve Çakır Nureddin’in mülâzemetlerinin paşaların arzı üzerine gerçekleştiği not edilmiştir.

Danişmendler arasında çalışkanlığı ile öne çıkan ya da bir hizmeti yerine getirenler ile mevleviyet rütbesindeki ulemanın çocuklarının, bir yetkilinin 
müstakil arzı aracıllğı ile mülâzım yazılma şekline "müstakilen ya da müstakil arz yolu ile mülâzemet" denmektedir ki bu defterde müstakilen mülâzım yazılan kişi sayısının çok fazla olduğu görülmektedir.

Bazı mülâzımlar hakkında ise kendi arzı ile mülâzım yazıldığı kaydı vardır. Mesela, "Gerden-dırâz Emîr ki merhûm Hacı Hasan oğlu tâlib-i ilimlerindendir. Kendü arzıyla mülâzım şod. Fî Ramazân sene 910 (Şubat-Mart 1505)” kaydı buna iyi bir örnektir.

Defterde sayıca az da olsa, mülâzım verme hakkına sahip müderrislerin, kendi muidlerini de "iadeden" mülâzım verdikleri görülmektedir. Örneğin Müvellâ Sinân-1 Acem, Amasya'daki Gök Medrese'de muidliğini yapan Veli’yi bu şekilde mülâzım vermiştir. Bu durum medresede mülâzemet uygulamasının XV. yüzyıl sonunda belli bir tekamül devresini tamamladığına işaret etmektedir.

Bazı mülâzımların ise hangi yolla mülâzemet sistemine dahil oldukları kayıtlardan anlaşılmamaktadır. Mesela, "Ve Zeyrek-zâde Mevlânâ Rükneddîn Çelebi'den mülâzım olan bunlardır. Fî evâsıt-1 âhiri'l-cumâdîn sene 908 ” başlı̆̆ı altında Muslihiddîn ve Kadri Çelebi'nin isimleri verilmekte ve kayıtta başka bir bilgi yer almamaktadır. Ancak bu durum belli aralıklarla mevleviyet derecesindeki kadı ve müderrislerin mülâzım vermesi usulü olan nevbet yoluyla mülâzım yazma usulünü akla getirmektedir. Fakat kayıtlardaki veriler bunu tam açıklayamadığı için buna dair net bir şey söylemek mümkün değildir.

Mülâzımlar kaydolunurken özellikle ulema ailesine mensup olanlar, kimin oğlu veya nereli oldukları ya da lakapları ile ayrıntılı bir şekilde yazılmıştır. Bu tür bir ayırıcı vasfı olmayanların ise sadece isimleri verilmiştir. Mesela, Mevlânâ Muhyiddîn'in, sefere katılıp Ergene yaylağında mülâzemete kabul edilen 4 talebesinden Abdüllatîf Çelebi'nin adı yazılırken "Mevlânâ Abdüllatîf Çelebi bin Mevlânâ Seydî el-müderris bi-medrese-i Sultâniye fî Edirne” şeklinde babasının Edirne'deki Sultaniye Medresesi'nde müderris olduğu kaydedilmekte bir diğer talebesi olan İvaz'ın ise sadece ismi verilmektedir. Bir diğer öğrencisi ise "Ubeydullâh bin Kutâs" şeklinde babasının adı ile birlikte yazılmıştır.

Defterin yeni mülâzımlardan oluşan bölümü toplam rakam belirtilerek tamamlanmıştır. Bu bölümün sonunda toplam mülâzım sayısını göstermek üzere "Yekûn: 113" diye bir not düşülmüştür. Aşağıdaki tabloda yeni mülâzımların dağlımı gösterilmiştir. 


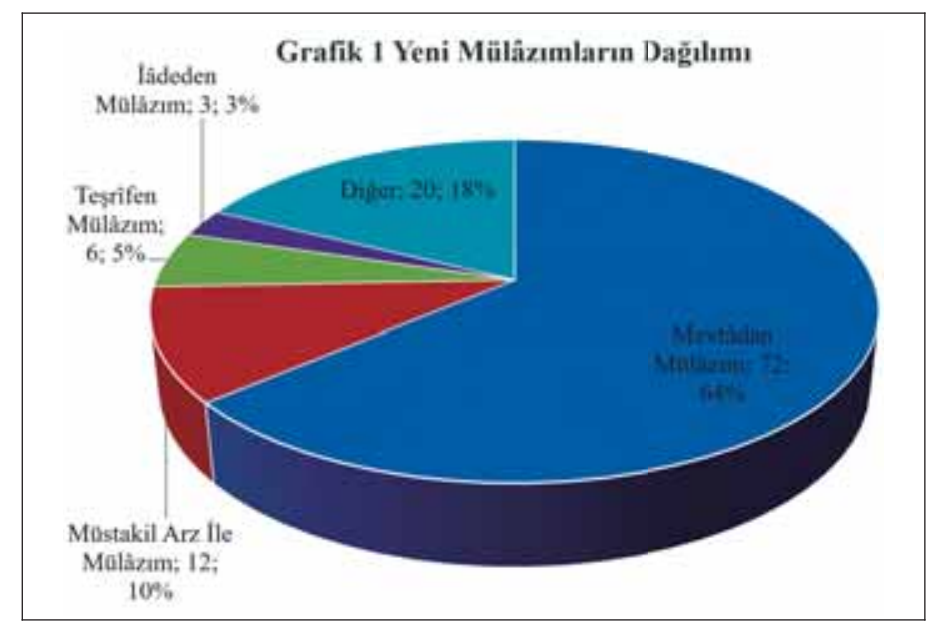

Buna göre 113 kişilik yeni mülâzım listesi içinde 72 kişiyle mevtâdan mülâzım alma usulü \% 64'lük bir orana tekabül etmekte olup sistemdeki en yüksek mülâzım alma yöntemi olarak göze çarpmaktadır. 12 kişi müstakil arz ile mülâzım yazılmış olup yeni mülâzımların \% 10'unu, teşrîfen mülâzım yazılan 6 kişi, \% 5'ini ve iâdeden mülâzım yazılan muidler ise 3 kişi olup \% 3 'ünü oluşturmaktadır. Kayıtlardan hangi yolla mülâzım yazıldığını anlayamadığımız 20 kişi ise \% 18 'lik diğer kısmı oluşturmaktadır.

Defterde yeni mülâzımlardan sonra Rumeli medreselerinden munfasıl olup İstanbul'da mülâzemette olan müderrisler kaydedilmiştir. Bu bölümün başlığı "Rûm-ili'nde medreseden ferâgat idüp hâliyâ bunda mülâzemetde olan bunlardır" şeklindedir. Bu bölümde, başlıktan da anlaşılacağı üzere, Rumeli’deki medreselerden kendi isteğiyle ayrılıp (ferâgat) mülâzemete devam edenler kaydedilmiştir. Aşağıdaki tabloda Rumeli medreselerinden munfasıl olan müderrisler ve hangi medreseden mülâzım oldukları ve varsa tarihi gösterilmiştir. 
Rumeli Medreselerinden Munfasıl Olup Mülâzemete Devam Eden Ulema

\begin{tabular}{|c|c|c|}
\hline Müderris & Munfasıl Olduğu Medrese & Tarih \\
\hline Muslihiddîn & Edirne'de Saraçlar Medresesi & Muharrem 909 \\
\hline Zeyrek-zâde & Üsküb Medresesi & 6 Âhirü'l-cumâdeyn 908 \\
\hline Muslihiddîn & Karaferye Medresesi & 19 Rebî́ü'l-evvel 911 \\
\hline Bedreddîn & Manastır Hacı Bey Medresesi & Belirtilmemiş \\
\hline Toplam & \multicolumn{2}{|c}{} \\
\hline
\end{tabular}

Rumeli müderrislerinden sonra ikinci olarak "Rûm-ili kazâsından ma'zûl olup hâliyâ bunda mülâzemetde olan bunlardır” başlığı altında Rumeli kazalarından ma'zûl kadılar zikredilmiştir. Burada 17 kişinin adı kaydedilmiş olup aşağıdaki tabloda ma'zûl kadılar, munfasıl oldukları kazalar ve tarihleri gösterilmektedir.

\section{Rumeli Kazalarından Munfasıl Olup Mülâzemete Devam Eden Ulema}

\begin{tabular}{|c|c|c|}
\hline Kadı & Munfasıl Olduğu Kaza & Tarih \\
\hline Arab oğlu Abdülkâdir Çelebi & Migalgara & Evveli'l-Cumâdeyn 910 \\
\hline Aydın & Filorina & Belirtilmemiş \\
\hline Seydî Gâzî Oğlu & Akkirman & Belirtilmemiş \\
\hline Sefer Şah & Priştine & 15 Rebî‘ü’l-âhir 910 \\
\hline Nûreddîn & İstefe & 15 Âhir-i Cumâdeyn 910 \\
\hline Şemseddîn & Adalar & 22 Receb 910 \\
\hline Alâaddîn & Akkirman & 15 Muharrem 910 \\
\hline Nûreddîn & İsfirlig & Evâsıt-1 Safer 910 \\
\hline Seydî Mehmed & Pravadi & 13 Zilhicce 910 \\
\hline Tâceddîn & Limnos & 7 Zilhicce 910 \\
\hline Kurt Bedreddîn & Görice & 9 Şevvâl 910 \\
\hline İskender & Alacahisâr & 2 Evveli'l-Rebî‘ayn 910 \\
\hline Muhyiddîn & Foça & 19 Şevvâl 909 \\
\hline Seydî Ali & İpsala & Rebî‘ü’l-âhir 910 \\
\hline Kalaycı Muhyiddîn & Zapline & 2 Âhir-i rebî‘ayn 911 \\
\hline Yahya Hoca? Oğlu & Hurpişte & Belirtilmemiş \\
\hline Arab-zâde Bektaş Çelebi & Sidrekapsi & Zilhicce 909 \\
\hline Toplam & \multicolumn{2}{|c|}{17} \\
\hline
\end{tabular}


Rumeli kayıtlarının ardından Anadolu medreselerinden munfasıl olan müderrislerin isimleri yazılmıştır. Burada "Anadolu medreselerinden ma'zûl olup hâliyâ bunda mülâzemetde olan bunlardır" başlığı âltında 31 kişinin ismi yazılmıştır. Bundan sonra da Anadolu kazalarından munfasıl olan kadıların isimleri kaydedilmiştir. Bu bölüme kadar listeleri verilen Rumeli ve Anadolu kadı ve müderrislerinin fiilen İstanbul'da mülâzemetde bulunduğu anlaşılmaktadır. Nitekim bu listelerden sonra Anadolu medreselerinden munfasıl olup İstanbul'da olmayan müderrislere ait kayıtlar "Anadolu müderrislerinden ma'zûl olup hâliyâ bunda olmayan bunlardır" başlığı altında verilmiştir. Buradaki sayı ise 5 'tir. Böylece Anadolu medreselerinden munfasıl olan müderris sayısı 36 olmaktadır. Aşağıdaki tabloda munfasıl müderrisler, munfasıl oldukları medreseler ve varsa tarihleri gösterilmektedir.

\section{Anadolu Medreselerinden Munfasıl Olup Mülâzemete Devam Eden Ulema}

\begin{tabular}{|c|c|c|}
\hline Müderris & Munfasıl Olduğu Medrese & Tarih \\
\hline IşıkKâsım & $\begin{array}{c}\text { Bursa Hacı İvaz Paşa } \\
\text { Medresesi }\end{array}$ & $\begin{array}{l}\text { Evâhir-i Muharrem } \\
908\end{array}$ \\
\hline Sinân Çelebi el-Yegânî & Bursa Eyne Bey Medresesi & 11 Cumâdi'l-ûlâ 909 \\
\hline Pîr Ahmed Çelebi & Tire Ferişte Oğlu Medresesi & $\begin{array}{l}15 \text { Cumâdiye'l-âhir } \\
910\end{array}$ \\
\hline Pîrî & Konya'da Altuniye Medresesi & Evâil-i Ramazân 907 \\
\hline Eyüb & Larende Hatuniye Medresesi & 9 Cumâdi'l-âhir 908 \\
\hline Acem Kemâl & Bursa İsâ Bey Medresesi & 8 Şa'bân 908 \\
\hline Muslihiddîn & Seferîhisâr Medresesi & 12 Ramazân 908 \\
\hline Muhyiddîn & Kastamonu Ata Bey Medresesi & 9 Şa'bân 908 \\
\hline Nûreddîn & Ermenek Medresesi & 8 Muharrem 909 \\
\hline Abdî & Balıkesrî Medresesi & 25 Şa'bân 908 \\
\hline Muhyiddîn & Tokat Yağıbasan Medresesi & 13 Safer 909 \\
\hline Kemâl & Amasya Halîfet Medresesi & 17 Cumâdiye'l-ûlâ 909 \\
\hline Muhyiddîn & Ankara Burucudiye? Medresesi & Evâil-i Cumâdî 909 \\
\hline Cevrî̀ & Eğirdir Medresesi & 24 Şa'bân 909 \\
\hline Bâyezîd & Sivas Dârüşşifâ Medresesi & $\begin{array}{l}\text { Selh-i Cumâdi'l-ûlâ } \\
909\end{array}$ \\
\hline
\end{tabular}




\begin{tabular}{|c|c|c|}
\hline $\begin{array}{c}\text { Taşköprü-zade Kasım } \\
\text { Çelebi }\end{array}$ & Bursa Aslaniye Medresesi & Gurre-i Ramzân 909 \\
\hline Safiyyüddîn & Kayseri Melik Gâzî Medresesi & 9 Muharrem 910 \\
\hline Sinân & İzmir Medresesi & 4 Cumâdi'l-âhir 910 \\
\hline Kâsım & $\begin{array}{c}\text { Kastamonu İsmail Bey } \\
\text { Medresesi }\end{array}$ & 26 Şevvâl 910 \\
\hline Abdî & Konya Sultân Veled Medresesi & Selh-i Şevvâl 910 \\
\hline Saçlı Abdî & Zile medresesi & 8 Zilhicce 910 \\
\hline Fakîrî & Beypazarı Medresesi & 27 Zilhicce 910 \\
\hline İ̀skât Abdî & Ankara Yeşil Medresesi & 8 Zilkade 910 \\
\hline Muhyiddîn & Tire Ya'kûb Bey Medresesi & 3 Muharrem 911 \\
\hline $\mathrm{Hac1}$ & İznik Dârü'l-hadîs Medresesi & Muharrem 911 \\
\hline Hayreddîn & Amasya Gök Medrese & 15 Rebîül-evvel 911 \\
\hline Taşköprü-zâde & Ankara Seyfî Medresesi & 8 Safer 909 \\
\hline Kara Hacı & Konya Nizâmiye Medresesi & Ramazân 908 \\
\hline Cemâl Hayreddîn & Aksaray Zincirli Medrese & Zilhicce 906 \\
\hline Muhyiddîn & İznik Dârü'l-hadîs Medresesi & Muharrem 907 \\
\hline Küçük Hacı & $\begin{array}{c}\text { Bursa Mevlânâ Hüsrev } \\
\text { Medresesi }\end{array}$ & 17 Cumâdiye’l-ûlâ 911 \\
\hline Muhyiddîn & Amasya Meydân Medresesi & Cumâdi'l-âhir 910 \\
\hline Paşa Çelebi & Aksaray Zincirlü Medrese & 15 Receb 910 \\
\hline Belirtilmemiş & Güzelhisâr Medresesi & 25 Safer 911 \\
\hline Kara Sinân & Konya Seyfî Medresesi & 8 Zilkade sene 910 \\
\hline Şemseddîn & $\begin{array}{c}\text { Amasya Mehmed Paşa } \\
\text { Medresesi }\end{array}$ & 21 Muharrem 911 \\
\hline Toplam & \multicolumn{2}{|l|}{36} \\
\hline
\end{tabular}

Anadolu medreselerinden sonra Anadolu kazalarından munfasıl kadıların ismi yazılmıştır. Tıpkı Anadolu medreselerinde olduğu gibi, Anadolu kazalarından munfasıl kadılar da iki başlık altında toplanmıştır. İlk olarak, "Anadolu kadılarından ma zûl olup hâliyâ bunda mülâzemetde olan bunlardır" başlığı alında 53 isim kaydedilmiş ve ardından "Anadolu kadılarından ma'zûl olup hâliyâ bunda olmayan bunlardır" başlığı altında 29 isim daha verilmiştir. Böylece Anadolu kazalarından munfasıl olan mülâzım sayısı 82'ye ulaşmaktadır. Aşağıdaki tabloda munfasıl Anadolu kadıları, munfasıl oldukları kaza ve tarih ile birlikte gösterilmektedir. 
Anadolu Kazalarından Munfasıl Olup Mülâzemete Devam Eden Ulema

\begin{tabular}{|c|c|c|}
\hline Kadı & Munfasıl Olduğu Kaza & Tarih \\
\hline İmâm-zâde Muhyiddîn & Kangır1 & 7 Cumâdiye'l-ûlâ 908 \\
\hline Ömer & Bacı & 5 Şa'bân 907 \\
\hline Muslihiddîn & Murtazâbâd & 25 Ramazân 907 \\
\hline Halîmî oğlu & Edremid & 15 Şevvâl 907 \\
\hline Sâlih & Yabanâbâd & Zilhicce 908 \\
\hline Müteaccim Şemseddîn & Çan & 8 Safer 908 \\
\hline Seyfullâh & Bozdoğan & 23 Cumâdi'l-âhir 908 \\
\hline Hasan & Kalkanlu & Gurre-i Receb 908 \\
\hline Muhyiddîn & Aydıncık & 5 Ramazân 908 \\
\hline Tâceddîn & Karaman'da Ereğli & Belirtilmemiş \\
\hline Haydar Çelebi & Sultânönü & 14 Muharrem 909 \\
\hline Muhyiddîn & Rize & 13 Safer 909 \\
\hline Dilârâm Şemseddîn & Mihaliççik & 3 Rebîül'-evvel 909 \\
\hline Abdüllatîf & İznik & Evâhir-i Rebîü'l-âhir 909 \\
\hline Çanlı Şeyh & Larende & Evâhir-i Zilkade 909 \\
\hline Muhyiddîn & Bilvîrân & Cumâdi'l-ûlâ 909 \\
\hline Ubeyd-zâde & Mudurnu & 29 Cumâdi'l-ûlâ 909 \\
\hline Vahî Çelebi & Geyve & 8 Cumâdi’l-âhir 909 \\
\hline Nûreddîn & Gönen & 10 Şa‘bân 909 \\
\hline Muslihiddîn & Yalakova & Gurre-i Ramazân 909 \\
\hline Kara Nûreddîn & Beybâzârı & 15 Ramazân 909 \\
\hline Hacı Hasan & İnönü & 24 Ramazân 909 \\
\hline Nûrullâh & Taraklıborlu & Şevvâl 909 \\
\hline Mezîd Çelebi & Çeşme & 27 Şevvâl 909 \\
\hline İmâd Oğlu & Kangırı & 8 Zilkade 909 \\
\hline Abdullâh & Saruhan Akhisârı & 19 Zilkade 909 \\
\hline Mehmed & Devrek & Zilhicce 909 \\
\hline Yûsuf Çırağı̂ & Taşköprü & 2 Rebîül'-evvel 910 \\
\hline Hayreddîn & Kula & Rebîül-evvel 910 \\
\hline Lütfü & Birgi & 2 Rebîü'l-evvel 910 \\
\hline Muhyiddîn & Ermeni & 13 Rebîüu’l-evvel 910 \\
\hline Alâaddîn & Gördes & 20 Rebî́üll-evvel 910 \\
\hline Elsüz Oğlu & Seferîhisâr & 6 Cumâdiye'l-ûlâ 910 \\
\hline
\end{tabular}




\begin{tabular}{|c|c|c|}
\hline Alâaddîn & Çeharşenbe & 20 Cumâdiye'l-ûlâ 910 \\
\hline Üveys & Arhova & Receb 910 \\
\hline İshâk Çelebi & Larende & 23 Cumâdiye'l-ûlâ 910 \\
\hline Bedreddîn & Gekivize & Gurre-i Receb 910 \\
\hline Kirmastili Oğlu & Mihaliç & 20 Ramazân 910 \\
\hline Tâceddîn & Söğüd & 3 Receb 910 \\
\hline Muslihiddîn & Bayramlu & 8 Zilkade 910 \\
\hline Muslihiddîn & Tosya & 16 Zilkade 910 \\
\hline Mehdî Şemseddîn & Beybazarı & 3 Cumâdiye'l-ûlâ 909 \\
\hline Velî Çelebi & Rize & 5 Şa'bân 910 \\
\hline Mes'ûd & Antalya & 22 Şa bân 910 \\
\hline Abdülkâdir & Murtazâbâd & 28 Zilhicce 910 \\
\hline Habîb & Bilvîrân & 18 Safer 911 \\
\hline Alâaddîn & Yalvaç & 4 Rebî́ül'-evvel 911 \\
\hline Velî & Atranaz & Belirtilmemiş \\
\hline Şucâ' & Ermeni & Belirtilmemiş \\
\hline Kaya & Kargu & 28 Zilhicce 910 \\
\hline Sâlih & Bayrâmlu & 29 Ramazân 909 \\
\hline Muslihiddîn & Alâiye & 11 Rebî‘üll-âhir 911 \\
\hline Abdullah & Sâhib-i Karahisârî & 14 Cumâdi'lûlâ 911 \\
\hline Müte'accim Balı & Bolvadin & 4 Safer 908 \\
\hline Şeyh-zâde & Aydın ilinden Yenişehir & Gurre-i Zilkade 909 \\
\hline Muhyiddîn & Bozüyük & Zilkade 909 \\
\hline Alâaddîn & Yabanâbâd & 26 Zilkade 909 \\
\hline Muslihiddîn & Bolvadin & 2 Zilhicce 909 \\
\hline Alâaddîn & Burdur & Evvel-i Cumâdi'l-ûlâ 910 \\
\hline Belirtilmemiş & Hoşalay & 4 Receb 910 \\
\hline Celâl & Simav & Receb 910 \\
\hline Alâaddîn & Satılmış & 3 Receb 910 \\
\hline Hayreddîn & Milas & 3 Şevvâl 910 \\
\hline Bilâl & Boyova & 16 Zilkade 910 \\
\hline Caffer & Ayazmend & 8 Zilhicce 910 \\
\hline Mahmûd & Labseki & 28 Zilhicce 910 \\
\hline Hâs Ahmed & Çeşme & 7 Zilhicce 910 \\
\hline Cemâl & Bergama & 8 Zilhicce 910 \\
\hline
\end{tabular}




\begin{tabular}{|c|c|c|}
\hline Mihen & Göl & 4 Ramazân 910 \\
\hline Karabaş Emîr & Çaka & 23 Ramazân 909 \\
\hline İslâm Oğlu & Sandıklı & 8 Şevvâl 909 \\
\hline Hasan & Yenice-i Eflegani & Rebî́ü’l-evvel 910 \\
\hline Abdî & Turhal & Rebîü̈̉l-evvel 910 \\
\hline Belirtilmemiş & Şuhud & Selh-i Zilhicce 910 \\
\hline Küçük Şemseddîn & Sinab? & 3 Muharrem 911 \\
\hline Analca Şemseddîn & Yabanâbâd & 3 Muharrem 911 \\
\hline Muhsin & Nif & 13 Safer 911 \\
\hline Bâzergân Oğlu & Anduğu & Evâil-i Rebî́ửl-evvel 911 \\
\hline Pîrî & Kaş & 16 Rebî́ül-evvel 911 \\
\hline Alâaddîn & Bolvadin & 7 Rebî́ử'lâhhir 911 \\
\hline Muhyiddîn & Teke Karahisârı & 9 Rebîưül-âhir 911 \\
\hline Muslihiddîn & Peçin & 9 Cumâdi'l-ûlâ 911 \\
\hline Toplam & \multicolumn{2}{|c|}{82} \\
\hline
\end{tabular}

Tablolarda da görüldüğü üzere defterde 4’ü Rumeli medreselerinden, 17’si Rumeli kazalarından, 36'sı Anadolu medreselerinden ve 82'si de Anadolu kazalarından olmak üzere toplam 139 munfasıl mülâzımın ismi yer almaktadır. Aşağıdaki grafikte munfasıl mülâzımların sayısı ve munfasıl mülâzımlar içindeki yüzdelik değeri gösterilmiştir.

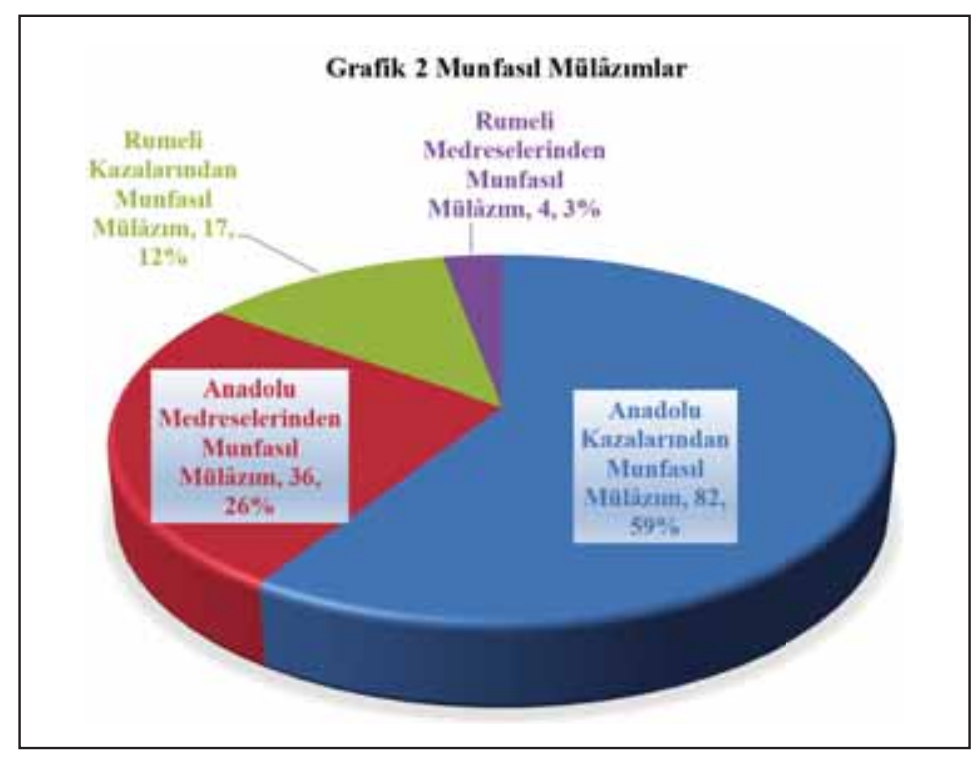


Munfasıl mülâzımlar bölümü tamamlandıktan sonra defterde "Cem'an: Hâzır ve gâib olan mülâzımlar: 253” notu düşülmüştür. Ancak yeni ve munfasıl mülâzımların toplamı 252 kişidir.

Defterde ayrıca İran coğrafyasından gelip de Osmanlı ilmiye sınıfına dahil olmak isteyen ve mülâzemete kabul edilen kişilerin isimleri de kaydedilmiştir. Bu kişilerin isimleri "Mülâzemete tâlib olan Acemler ve Müte'accim bunlardır ki zikr olunur" başl lğı altında verilmiştir. Bu şekilde mülâzemete kabul edilenlerin sayısı 10'dur. Burada dikkat çeken husus köklü bir medrese ve ilim geleneği olan İran coğrafyasından müderrislerin de Osmanlı ilmiye sınıfına katılma arzularıdır. Yine dikkati çeken bir diğer husus da Acem asıllı olmayan ancak bu coğrafyadan geldiği için "Mütéaccim" şeklinde tanımlanan kişilerin varlığıdır. Tarih verilmeden sadece isimleri, lakapları veya nereli oldukları yazılan bu 10 kişi, muhtemelen yeni filizlenen Şah İsmail yönetiminden kaçıp Osmanlı'ya sığınan ulema olmalıdır.

İhtiva ettiği kayıtlar bir bütün olarak değerlendirildiğinde defterde 113 yeni mülâzım, 139 munfasıl mülâzım ve 10 'u da Acem ve Müte'accim olmak üzere 262 mülâzımın sisteme dahil olduğu veya yer değiştirdiği anlaşılmaktadır. Munfasıl mülâzımlar 139 kişi ve \% 53'lük bir oran ile yeni mülâzımlardan daha fazladır. Defterdeki veriler topluca değerlendirildiğinde şu tablo ortaya çımaktadır:

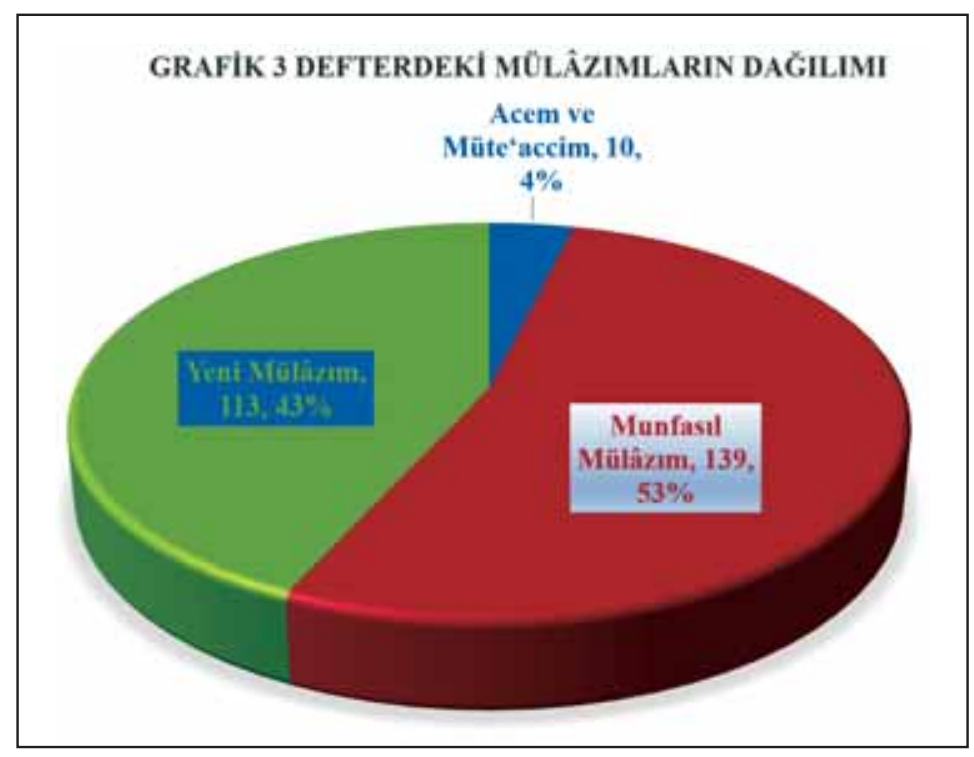


Defterin muhtevası, mülâzemet sisteminin II. Bayezid döneminde şekillenmiş olduğunu, ilmiye sınıfına yeni girenlerin yeni mülâzım olarak adlandırıldığını ve mülâzemet usulünün de ölüm, terfi, teşrif ve sair sebeplere bağlı olarak şekillendiğini göstermektedir. 906-911 (1501-1506) tarihli mülâzemet kayıtlarının analizi II. Bayezid döneminde bile kadı ve müderrislerin hayat boyu bir görevi tasarruf etme durumunun olmadığını, azil yoluyla görevden infisalin mevcut olduğunu, azil uygulamasının kadıların yanı sıra müderrisler için de geçerli olduğunu ortaya koymaktadır.

\section{Sonuç}

Bu çalışmada Topkapı Sarayı Arşivi'nde 5065/1 numarada kayıtlı olup 906911 (1501-1506) tarihleri arasındaki kayıtları ihtiva eden bir mülâzemet defteri değerlendirilmiştir. İncelenen defter, bilinen ilk mülâzemet ruznamçesi olan 951959 (1544-1556) tarihli ruznamçeden 43 yll önce düzenlenmiş olup mülâzemet sisteminin II. Bayezid döneminde mevcut olduğunu ortaya koymaktadır. Defter, Kanuni öncesi dönemi mülâzemet sistemini yansıtması ve Ebussuud düzenlemeleri öncesi mülâzemetin varlığını kanıtlaması bakımından büyük önem arz eder. Defter, mülâzemet sisteminin XVI. yüzyılın hemen başlarında, II. Bayezid zamanında şekillendiğini göstermekte ve sistemin ilk dönemine dair ayrıntılı bilgi vermektedir. Defterde, hem medreseden yeni mezun olup kadılık ve müderrislik için sıra bekleyen yeni mülâzımlar hem de bir kaza ya da medresede görev yaptıktan sonra başka bir göreve atanana kadar mülâzemet edecek kimselerin kayıtları mevcuttur. Defter, ilmiye sınıfına yeni girenlerin yeni mülâzım olarak adlandırıldığını ve mülâzemet usulünün de ölüm, terfi, teşrif ve sair sebeplere bağlı olarak şekillendiğini göstermektedir. 906-911 (1501-1506) tarihli mülâzemet kayıtlarının analizi II. Bayezid döneminde bile kadı ve müderrislerin hayat boyu bir görevi tasarruf etme durumunun olmadığını, azil yoluyla görevden infisalin mevcut olduğunu, azil uygulamasının kadıların yanısıra müderrisler için de geçerli olduğunu ortaya koymaktadır. 
Yeni Bir Belgeye Göre XVI. Yüzyılın İlk Yarısında Osmanlı Mülâzemet Sistemi

Öz • Bu çalışmada Osmanlı ilmiye mesleğine giriş için temel şartlardan biri olan mülâzemet sisteminin II. Bayezid döneminde şekillenmiş olduğunu gösteren 906911 (1501-1506) tarihli bir mülâzemet defteri incelenmektedir. XV. yüzyılın sonlarından itibaren var olduğu bilinmesine rağmen uygulamasının nasıl ve ne şekilde yürütüldüğü meçhul kalan mülâzemet sisteminin, genel olarak XVI. yüzyılın ikinci yarısında Kanuni döneminde Ebussuud Efendi tarafından sistemleştirildiği kabul görmektedir. Mülâzemet hakkında İsmail Hakkı Uzunçarşılı'dan başlayarak birçok araştırmacı konunun farklı yönleriyle ilgili çalışmalar yapmışlarsa da sistemin nasıl gelişip şekillendiği meçhul kalmıştır. Her şeyden önce ilmiye teşkilatında mülâzemetin ne zaman başladığı tespit edilememiştir. Bu çalışmanın konusunu teşkil eden defter ise mülâzemet sisteminin XVI. yüzyılın hemen başlarında, II. Bayezid zamanında sistemli olarak uygulandığını göstermektedir. Defter, tespit edilen en eski mülâzemet defteri olup bu çalışmada defterdeki kayıtlardan hareketle mülâzemet sisteminin II. Bayezid dönemindeki durumu, verilerin ayrıntılı analizi ile değerlendirilecektir.

Anahtar kelimeler: II. Bayezid, İlmiye, Rumeli Kazaskerliği, Kazasker ruznamçesi, Kaza, Kadı, Medrese, Müderris, Mülâzemet, 16. yy. 
906-911 (1501-1506) Tarihli Mülazemet Defteri (TSA 5065/1)

[1b]

Tafsîl oldur ki mevâlî-yi müteveffâdan kalan ve gayrıdan mülâzım olup hâliyâ mevcûd olan yeni mülâzımları beyân ider.

Merhûm Hâce hazretlerinden kalan tâlib-i ilimler bunlardır:

Mevlânâ Küçük Emîr ve Alâaddîn Çerçinî ve Kayış Muhyiddîn ve Acem Muhyiddîn ve Süleymân ve Hotaz Şucâ‘ ve Kâsım Çelebi ve Sinân el-Bezzâzî ve Ahmed Çelebi ve Mehmed bin Pirinçci ve Âzad Çelebi

Yekûn: 11

Merhûm Kirmastili’den kalan tâlib-i ilimler bunlardır:

Mevlânâ Üveys ve Helvac1-oğlu Mehmed ve Karamanlu Hüsâm ve Velî bin Arab ve Şemseddîn el-Bursevi ve Kara Muhyiddîn ve Süleyman ve Sinan bin Kazancı ve Kadıasker Muslihiddîn ve Balık Şucâ‘ ve Işk Abdî ve Şeref ve Hüseyin bin Ehad ve Küçük Ali ve Kozcu Ali'si

Yekûn: 15

Merhum Hatîb-zâde'den kalan tâlib-i ilimler bunlardır:

Mevlânâ Kemâl ve Süleymân ve Abdülkerîm bin Baklacı ve Velî bin Elvân ve Mevlânâ Yahya ve Ahmed eş-şehîr bi-Arab ve Azîz Ece-zâde ve Kara Kâsım Mütéaccim

Yekûn: 8

[2a]

Ve merhum Yaralıca'dan kalan tâlib-i ilimler bunlardır:

Mevlânâ Alâaddîn ve Hazm Şemseddîn ve Muhyiddîn ve Mûsâ ve Kemâl oğlu ve Hayreddîn ve Müte'accim Muhyiddîn ve Safiyyüddîn ve Mevlânâ Emre

Yekûn: 9

Ve merhûm Ahaveyn'den kalan tâlib-i ilimler bunlardır:

Hacı İvaz ve Gonca Ali ve Mustafâ ve Ali Kahhâr ve İvaz ve diğer Mustafâ ve Sa'dî

Yekûn: 7 
Ve Merhûm Efdal-zâde’den kalan tâlib-i ilimler bunlardır:

Mevlânâ Nakîzî Bâyezid ve Ömer ve Tekelü Abdî ve Ali bin Neccâr ve Kara Üveys karındaşı Muhyiddîn ve Îsâ ve Kâsım ve Seydî Ali

Yekûn: 8

Bu zikr olunan müteveffâ mevâlîden kalan cümle tâlib-i ilimler sene tis'a ve tis'amie Muharrem'inin 10. gününde pâye-i serîr-i a'lâya arz olunup mülâzemete kabûl olundular.

Mevlânâ Emîr el-müderris: Amasya Medresesi'ne müderris oldukda mülâzım virdüğüi bunlardır. Fî yevmi'l-isneyn, tâsi‘ ve işrîn min-Muharrem sene 911

Mevlânâ Ya'kûb Çelebi bin Hasan ve Muhyiddîn bin Hüseyin

Merhûm Hacı Hasan oğlu Mevlânâ Muhyiddîn’in mülâzımları ki yaylakda Ergene yurdunda ta'yîn olunan bunlardır. Fî evâsıt-1 Rebî‘ü’l-âhir sene 910

Mevlânâ Abdüllatîf Çelebi bin Mevlânâ Seydî el-müderris bi-medrese-i Sultâniye fî Edirne

Ve Mevlânâ Muhyiddîn eş-şehîr bi-Cemâl Karındaşı ve İvaz ve Ubeydullâh bin Kutas

[2b]

Ol hînde fahrü'l-ulemâi'l-izâm Mevlânâ Müeyyed-zâde hazretlerinden mülâzım olan bunlardır. Zikr olunur:

Mevlânâ Memi Çelebi bin El-hac Hasan ve Mevlânâ Zeyneddîn ve Mevlânâ Dâvûd ve Süleymân

Ve Sâbıkâ kadıasker olan Mevlânâ Alâaddîn'den mülâzım olan bunlardır. Fî Rebî'ü'l-âhir sene seb'a ve tis'amie

Mevlânâ Emîr Hasan ve Hacı Sinân ve Hacı Mehmed Siyâh

Cemâl Çelebi veled-i Ali Çelebi el-müftî bi-arz-ı paşayân fî evâhir-i ahîrürrRebî‘ayn sene 908 
Ve Çakır Nûreddîn mu'îd-i Ali Çelebi el-mezbûr bi-arz-ı paşayân fî evâil-i evveli'l-Cumâdeyn sene 908

Kemâl an-tâlib-i ulemâ Hatîb-zâde bi-iltimâs-1 İskender Paşa fî evâhir-i Ramazân sene 908

Ve Hüsrev Çelebi bin Mehmed Çelebi el-Cellâbî

Ve Zeyrek-zâde Mevlânâ Rükneddîn Çelebi'den mülâzım olan bunlardır. Fî evâsıt-1 âhiri'l-Cumâdeyn sene 908

Muslihiddîn ve Kadrî Çelebi

Ve Mevlânâ Nûreddîn eş-şehîr bi-Leys Çelebi'den mülâzım olanlardan Fî evâsıt-1 Zî̀l-ka'de sene 908 Mevlânâ Muslihddîn

Ve Mevlânâ Efdal-zâde kendü hayâtında virdüğü mülâzımlardan bâkî bunlardır: Fî Rebî́ül'-evvel sene 908

Mevlânâ Muhyiddîn Çelebi bin Fenârî ve Mevlânâ Süleymân

Mehmed Çelebi bin Ali Çelebi el-müftî bi-arz-1 Paşayân mülâzım-şod. Fî 12 Safer sene 911

Merhûm Kâsım Çelebi oğlu Mehmed Çelebi mülâzım şod. Fî 12 Muharrem sene 910

Ve Mevlânâ Hâfız-1 Karabağî merhûm Hacı Hasan oğlu arzıyla mülâzım şod. Fî Cumâdiye'l-âhir sene 910

Ve Hasan mevlâsıYa'kûb Paşa mektûbuyla mülâzım şod. Fî sene 908

\section{[3a]}

Ve Baldır oğlu Nûrullâh paşalar arzıyla mülâzım şod. Fî 16 Rebî́ül'l-evvel sene 910

Merhûm Ahi müderrisin oğlu Abdurrahman Çelebi mülâzım şod. Fî 17 Receb sene 910

Ve Ahmed Çelebi bin Hızır Bey mu'îdi Dâvud mülâzım şod. Fî 17 Receb sene 910

Yeniçeri ağasının hocası Mevlânâ Murâd Ağa iltimâsıyla mülâzım şod. Fî Evâil-i Cumâdiye'l-ûlâ sene 910 
Mehmed Şah Çelebi bin Efdal-zâde babası fevtinden sonra mülâzım şod.

Ve merhûm Gürânî oğlu İbrahim Çelebi mülâzım şod.

Ve merhûmun talebesinden İbrahim Paşa oğulları hocası Nûreddîn ve Yahya Paşa oğulları hocası Mehmed eş-şehîr bi-İbsalalu Çelebi mülâzım şod. Fî Cumâdi'l-âhir sene 908

Hızır Bey Çelebi bin Ahmed Paşa el-müftî mülâzım şod. Fî Zilhicce sene 909

Yarhisâr oğlunun oğlu Mehmed Çelebi mülâzım şod. Fî Rebî‘üll-evvel sene 909

Gerden-dırâz Emîr ki merhûm Hacı Hasan oğlu tâlib-i ilimlerindendir. Kendü arzıyla mülâzım şod. Fî Ramazân sene 910

Merhûm Mevlânâ Arab tâlib-i ilimlerinden

Bostân Çelebi ve Canbâz oğlu Abdurrahman

Ve merhûm Ali Çelebi el-Yegânî'nin fevtinden sonra beş mülâzım alındı. Bunlardır fî Muharrem sene 909

Gürez Ali ve Ca'fer ve Mehmed Çelebi ve Şa'bân ve Şeyhî

Defa Hüseyin Ağa iltimâsıyla mezkûrun tâlib-i ilimlerinden Ak Ali mülâzım şod.

Fî Şa ${ }^{\circ}$ bân sene 910

Ve merhûm Hüseyin Çelebi el-Yegânînin iki oğlu ki Mehmed Çelebi ve Mustafa Çelebi'dir ve bir mu'îdi ki Gürez Ali'dir mülâzım oldular. Fî evâsıt-1 Zilkade sene 910

\section{Mevlânâ Kara Balı’dan iki mülâzım alındı ki bunlardır:}

Maksûd Şemseddîn ve İshâk

\section{[3b]}

Merhûm Hâce tâlib-i ilimlerinden Nişancı Mehmed Paşa oğlu mülâzım şod.

Ve Ömer Çelebi hîş-i Halîlî mülâzım şod.

Ve Mudurnî Muhyiddîn ki Kâsım Çelebi tâlib-i ilimlerindendir. 
Ve Saru Sinânoğlu tâlibi'l-ilm Muslihiddîn bi-arz-1 paşayân fî sene Rebî́ü'levvel sene 910

Amasya’daki Gök Medrese'nin mu îdi Müvellâ Sinân-1 Acem'den kalanVelî

\section{Yekûn: 113}

\section{Rûm-ili'nde medreseden ferâgat idüp hâliyâ bunda mülâzemetde olan bunlardir:}

Edirne'de Saraçlar Medresesi'nden Mevlânâ Muslihiddîn fî Muharrem sene 909

Üsküb Medresesi'nden ma'zûl olan Zeyrek-zâde fî 6 Âhirü’l-cumâdîn sene 908

Karaferye Medresesi'nden Muslihiddîn fî 19 Rebî̀ü̉l-evvel sene 911

Manastır'da Hacı Bey Medresesi'nden Mevlânâ Bedreddîn

\section{Yekûn: 4}

\section{Rûm-ili kazâsından ma'zûl olup hâliyâ bunda mülâzemetde olan bun- lardir:}

Migalkara kazâsından Mevlânâ Arab oğlu Abdülkâdir Çelebi fî evveli'lCumâdeyn sene 910

Filorina kazâsından mázûl Mevlânâ Eyvin?

Ve Akkirman kazâsından Seydî Gâzî oğlu

Ve Priştine kazâsından Sefer Şah fî 15 Rebî̀ü̉l-âhir sene 910

Ve İstife kazâsından Nûreddîn fî 15 Âhir-i Cumâdeyn sene 910

Ve Adalar kazâsından Şemseddîn fî 22 Receb sene 910

Akkirman kazâsından Alâaddîn fî 15 Muharrem sene 910

İsfirlig kazâsından Nûreddîn fî evâsıt-1 Safer sene 910

Ve Pravadi kazâsından Seydî Mehmed fî 13 Zilhicce sene 910

Limnos kazâsından Tâceddîn fî̀ 7 Zilhicce sene 910

Görice kazâsından Kurt Bedreddîn fî 9 Şevvâl sene 910

Alacahisâr kazâsından İskender fî 2 evveli'l-Rebî‘ayn sene 910 


\section{[4a]}

Foça kazâsından Muhyiddîn fî 19 Şevvâl sene 909

İpsala kazâsından Seydî Ali fî Rebîuül-âhir sene 910

Zapline kazâsından Kalaycı Muhyiddîn fî 2 Âhir-i rebî'eyn sene 911

Hurpişte kazâsından Yahya Fele oğlu

Sidrekapsi kazâsından Mevlânâ Arab-zâde Bektaş Çelebi fî Zilhicce sene 909

\section{Yekûn: 17}

\section{Anadolu medreselerinden ma'zûl olup hâliyâ bunda mülâzemetde olan bunlardir:}

Bursa'da Hacı İvaz Paşa Medresesi’nden ma‘zûl Işk Kâsım fî evâhir-i Muharrem sene 908

Bursa'da Eyne Bey Medresesi'nden mázûl Sinân Çelebi el-Yegânî fî 11 Cumâdi'l-ûlâ sene 909

Tire'de Ferişte oğlu Medresesi'nden Pîr Ahmed Çelebi fî 15 Cumâdiye'l-âhir sene 910

Konya’da Altuniya Medresesi'nden Pîrî fî evâil-i Ramazân sene 907

Larende’de Hatuniye Medresesi'nden Eyüb fî 9 Cumâdi'l-âhir sene 908

Bursa'da İsâ Bey Medresesi'nden Acem Kemâl fî 8 Şa ‘bân sene 908

Seferihisar Medresesi'nden Muslihiddîn fî 12 Ramazân sene 908

Kastamonu'da Ata Bey Medresesi'nden Muhyiddîn fî 9 Şa 'bân sene 908

Ermenek Medresesi'nden ma'zûl Nûreddîn fî 8 Muharrem sene 909

Balıkesrî Medresesi’nden Abdî fî 25 Şa 'bân sene 908

Tokat'da Yağıbasan Medresesi'nden Muhyiddîn fî 13 Safer sene 909

Amasya'da Halîfet Medresesi'nden Kemâl fî 17 Cumâdiye'l-ûlâ sene 909

Ankara’da Buruciye? Medresesi'nden Muhyiddîn fî evâil-i Cumâdî sene 909

Eğirdir Medresesi’nden Cevrî fî 24 Şa ‘bân sene 909

Sivas'da Dârüş̧ifâ Medresesi'nden Bâyezîd fî selh-i Cumâdi'l-ûlâ sene 909

Bursa Aslaniye Medresesi'nden Taşköprü-zâde Kasım Çelebi fî gurre-i Ramzân sene 909 


\section{$[4 b]$}

Kayseri'de Melik Gâzî Medresesi'nden Safîüddîn fî 9 Muharrem sene 910 İzmir Medresesi'nden Sinân fî 4 Cumâdi'l-âhir sene 910 Kastamonu'da İsmaîl Bey Medresesi'nden Kâsım 26 Şevvâl sene 910 Konya'da Sultân Veled Medresesi'nden Abdî fî selh-i Şevvâl sene 910 Zile'de olan medreseden ma'zûl Saçlı Abdî fî 8 Zilhicce sene 910 Beybazarı Medresesi'nden Fakîrî fî 27 Zilhicce sene 910 Ankara’da Yeşil Medresesi'nden İskât Abdî fî 8 Zilkade sene 910 Tire’de Ya 'kûb Bey Medresesi’nden Muhyiddîn fî 3 Muharrem sene 911 İznik'de Dârü'l-hadîs Medresesi'nden Hacı fî Muharrem sene 911 Amasya’da Gök Medrese'den Hayreddîn fî 15 Rebîül-evvel sene 911 Ankara'da Seyfî Medresesi'nden Taşköprü-zâde fî 8 Safer sene 909 Konya'da Nizâmiye Medresesi'nden Kara Hacı fî Ramazân sene 908 Aksaray'da Zincirlü Medrese'den Cemâl Hayreddîn fî Zilhicce sene 906 İznik'de Dârü'l-hadîs Medresesi'nden Muhyiddîn fî Muharrem sene 907 Bursa'da Mevlânâ Hüsrev Medresesi'nden Küçük Hacı fî 17 Cumâdiye'l-ûlâ sene 911

\section{Yekûn: 31}

\section{Anadolu kadılıklarından ma'zûl olup hâliyâ bunda mülâzemetde olan bunlardır:}

Kangırı kazâsından İmâm-zâde Muhyiddîn fî 7 Cumâdiye’l-ûlâ sene 908

Bacı kazâsından Ömer fî 5 Şa bân sene 907

Murtazâbâd kazâsından Muslihiddîn fî 25 Ramazân sene 907

Edremid kazâsından Halîmî oğlu fî 15 Şevvâl sene 907

Yabanâbâd kazâsından Sâlih fî Zilhicce sene 908

Çan kazâsından Müteaccim Şemseddîn fî 8 Safer sene 908

[5a]

Bozdoğan kazâsından Seyfullâh fî 23 Cumâdi'l-âhir sene 908 Kalkanlu kazâsından Hasan ma'zûl şod. Fî gurre-i Receb sene 908 
Aydıncık kazâsından Muhyiddîn fî 5 Ramazân sene 908 Karaman'da Ereğli kazâsından Tâceddîn

Sultânönü kazâsından Haydar Çelebi fî 14 Muharrem sene 909

Rize kazâsından Muhyiddîn fî 13 Safer sene 909

Mihaliççik kazâsından Dilârâm Şemseddîn fî 3 Rebîül-evvel sene 909

İznik kazâsından Abdüllatîf fî evâhir-i Rebiü'l-âhir sene 909

Larende kazâsından Çanlı Şeyh fî evâhir-i Zilkade sene 909

Bilviran kazâsından Muhyiddîn fî Cumâdi'l-ûlâ sene 909

Mudurnu kazâsından Ubeyd-zâde fî 29 Cumâdi'l-ûlâ sene 909

Geyve kazâsından Vahî Çelebi fî 8 Cumâdi'l-âhir sene 909

Gönen kazâsından Nûreddîn fî 10 Şa bân sene 909

Yalakova kazâsindan Muslihiddîn fî gurre-i Ramazân sene 909

Beybazarı kazâsından Kara Nûreddîn fî 15 Ramazân sene 909

İnönü kazâsından Hacı Hasan fî 24 Ramazân sene 909

Taraklıborlu kazâsından Nûrullâh fî Şevvâl sene 909

Çeşme kazâsından Mezîd Çelebi fî 27 Şevvâl sene 909

Kangırı kazâsından İmâd oğlu fî 8 Zilkade sene 909

Saruhan Akhisâr' indan Abdullâh fî 19 Zilkade sene 909

Devrek kazâsından Mehmed fì Zilhicce sene 909

Taşköprü kazâsından Yûsuf Çırağı̂ fî 2 Rebiü'l-evvel sene 910

Kula kazâsından Hayreddîn fî Rebîü'l-evvel sene 910

Birgi kazâsından Lütfü fî 2 Rebîül-evvel sene 910

\section{[5b]}

Ermeni kazâsindan Muhyiddîn fî 13 Rebî́üll-evvel sene 910

Gördes kazâsından Alâaddîn fî 20 Rebî́ü'l-evvel sene 910

Seferîhisâr kazâsından Elsüz oğlu fî 6 Cumâdiye'l-ûlâ sene 910

Çehârşenbe kazâsından Alâaddîn fî 20 Cumâdiye'l-ûlâ sene 910

Arhova kazâsından Üveys fî Receb sene 910

Larende kazâsından İshâk Çelebi fî 23 Cumâdiye'l-ûlâ sene 910 
Gekivize kazâsından Bedreddîn fî gurre-i Receb sene 910

Mihaliç kazâsından Kirmastili oğlu fî 20 Ramazân sene 910

Söğüd kazâsından Tâceddîn fî 3 Receb sene 910

Bayramlu kazâsından Muslihiddîn fî 8 Zilkade sene 910

Tosya kazâsından Muslihiddîn fî 16 Zilkade sene 910

Beybazarı kazâsından Mehdî Şemseddîn fî 3 Cumâdiye'l-ûlâ sene 909

Rize kazâsindan Velî Çelebi fî 5 Şa 'bân sene 910

Antalya kazâsından Mes'ûd fî 22 Şa'bân sene 910

Murtazâbâd kazâsından Abdülkâdir fî 28 Zilhicce sene 910

Bilvirân kazâsından Habîb sene fî 18 Safer sene 911

Yalvaç kazâsından Alâaddîn fî 4 Rebî́ử'l-evvel sene 911

Atranaz kazâsından Velî

Ermeni kazâsından Şucâ‘

Kargu kazâsından Kaya fî 28 Zilhicce sene 910

Bayramlu kazâsından Sâlih fî 29 Ramazân sene 909

Alâiye kazâsından Muslihiddîn fî 11 Rebî́üul-âhir sene 911

Sâhib-i Karahisârî kazâsından Abdullah fî 14 Cumâdi'lûlâ sene 911

\section{Yekûn: 53}

Cem'an: Yeni mülâzımlar ve kazâdan ve tedrîsden ma'zûl olanlar ki hâzırlardır. 216

[6a]

Anadolu müderrislerinden ma'zûl olup hâliyâ bunda olmayan bunlardır:

Amasya'da Meydan Medresesi müderrisi Muhyiddîn fî Cumâdi'l-âhir sene 910

Aksaray'da Zincirlü Medrese müderrisi Paşa Çelebi fî 15 Receb sene 910

Güzelhisâr Medresesi müderrisi fî 25 Safer sene 911

Konya'da Seyfî Medresesi müderrisi Kara Sinân fî 8 Zilkade sene 910

Amasya'da Mehmed Paşa Medresesi müderrisi Şemseddîn fî 21 Muharrem sene 911 


\section{Yekûn: 5}

\section{Anadolu kadılarından ma'zûl olup hâliyâ bunda olmayan bunlardır:}

Bolvadin kadısı Mütéaccim Balı fî 4 Safer sene 908

Aydın ilinde Yenişehir kadısı Şeyh-zade fî gurre-i Zilkade sene 909

Bozüyük kadısı Muhyiddîn fî Zilkade sene 909

Yabanâbâd kadısı Alâaddîn fî 26 Zilkade sene 909

Bolvadin kadısı Muslihiddîn fî 2 Zilhicce sene 909

Burdur kadısı Alâaddîn fî Evvel-i Cumâdi'l-ûlâ sene 910

Hoşalay kadısı fî 4 Receb sene 910

Simav kadısı Celâl fî Receb sene 910

Satılmış kadısı Alâaddîn fî 3 Receb sene 910

Milas kadısı Hayreddîn fî 3 Şevvâl sene 910

Boyova kadısı Bilâl fî 16 Zilkade sene 910

Ayazmend kadısı Ca'fer fì 8 Zilhicce sene 910

Labseki kadısı Mahmûd fî 28 Zilhicce sene 910

Çeşme kadısı Hâs Ahmed fî 7 Zilhicce sene 910

Bergama kadısı Cemâl fî 8 Zilhicce sene 910

Göl kadısı Mihen fî 4 Ramazân sene 910

Çağa kadısı Karabaş Emîr fî 23 Ramazân sene 909

Sandıklı kadısı İslâm oğlu fî 8 Şevvâl sene 909

\section{[6b]}

Yenice-i Eflegani kadısı Hasan fî Rebî́üu'l-evvel sene 910

Turhal kadısı Abdî fî Rebî́ü'l-evvel sene 910

Şuhud kadısı fî selh-i Zilhicce sene 910

Sinab kadısı Küçük Şemseddîn fî 3 Muharrem sene 911

Yabanâbâd kadısı İnalca Şemseddîn fî 3 Muharrem sene 911

Nif kadısı Muhsin fî 13 Safer sene 911 
Anduğu kadısı Bâzergân oğlu fî evâil-i Rebîuüll-evvel sene 911

Kaş kadısı Pîrî fî 16 Rebî́ử'l-evvel sene 911

Bolvadin kadısı Alâaddîn fî 7 Rebî́ü'l-âhir sene 911

Teke Karahisârı kadısı Muhyiddîn fî 9 Rebî́ü'l-âhir sene 911

Peçin kadısı Muslihiddîn fî 9 Cumâdi'l-ûlâ sene 911

Yekûn: 29

Cem'an: Hâzır ve gâib olan mülâzımlar: 253

Mülâzemete tâlib olan Acemler ve Müte'accim bunlardır ki zikr olunur:

Mevlânâ Ali İsfahanî Mevlânâ Hüseyin Şirvanî Mevlânâ Ali Türk Mevlânâ Ali Germiyânî Mevlânâ Can Kara Siyâh ve Muslihiddîn el-müte'accim ve Hüsrev Çelebi veled-i Onsekiz ve Baba Mehmed ve Mevlânâ Hüseyin Tebrizî ve Tatar Hamza

Yekûn: 10 


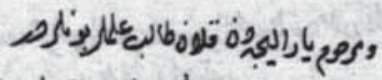

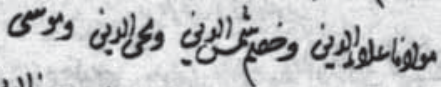

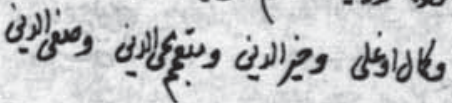
the

وبطو6)

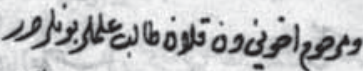

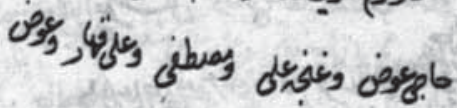

gré cyes

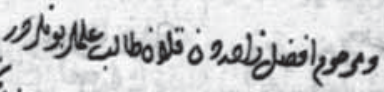

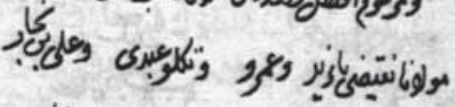

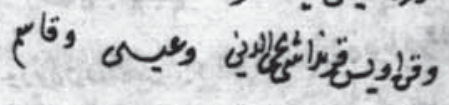

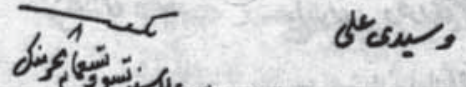

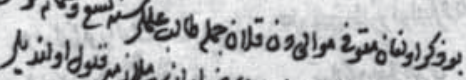

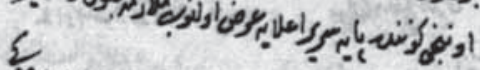

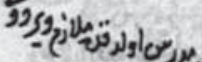

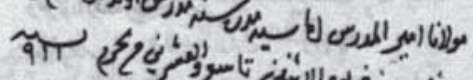

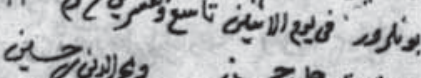

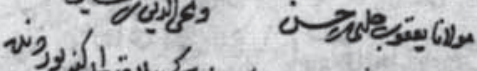

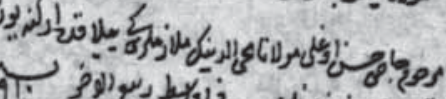
تعيبن (ب)

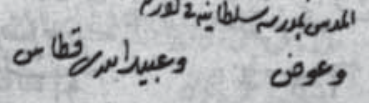

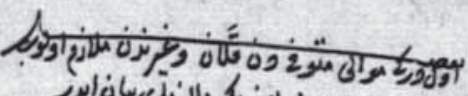

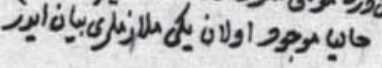

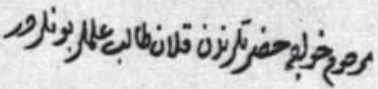

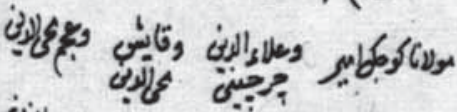

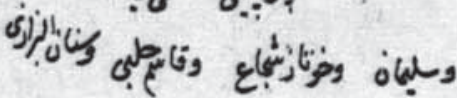

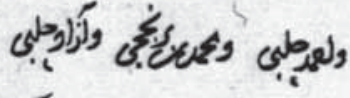<smiles>CC=CCCC</smiles>

sو

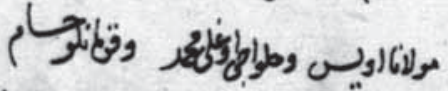

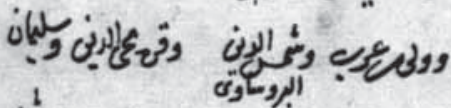

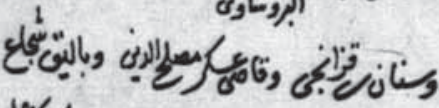

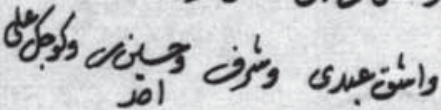<smiles>CC#CCOCCOCCOCC</smiles>

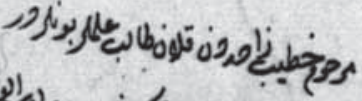

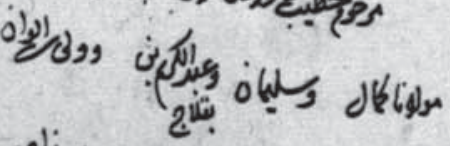

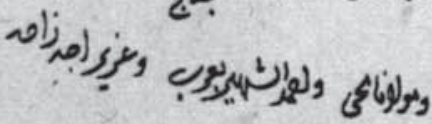

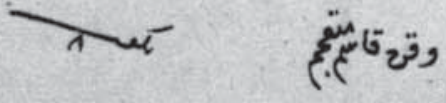

\section{D.05605.0001.00}




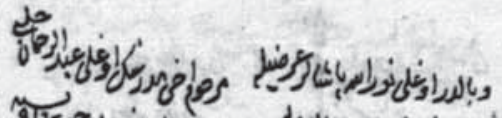

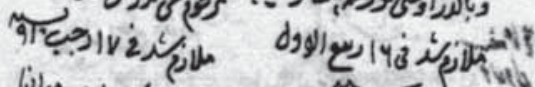

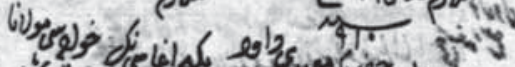

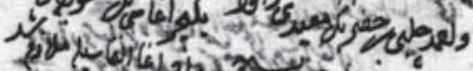
भा

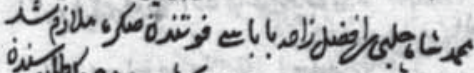

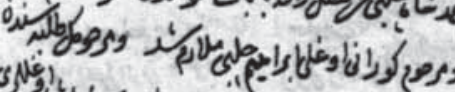
$0 \mathrm{NO}_{\mathrm{g}}$

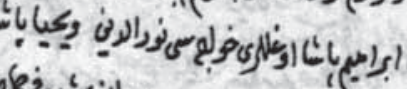

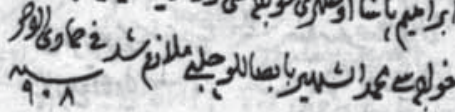

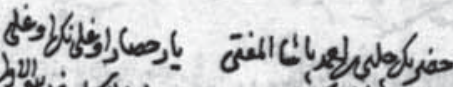
भ.व १.व.

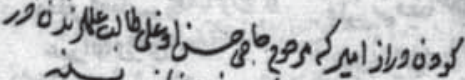

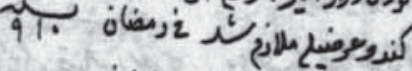

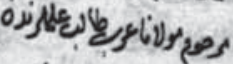

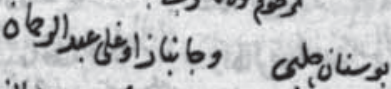

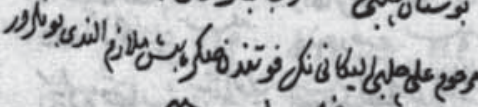

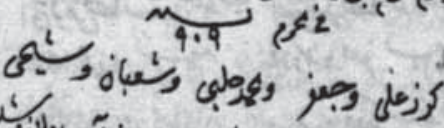

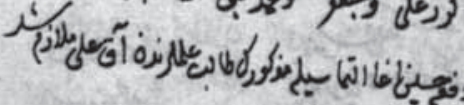

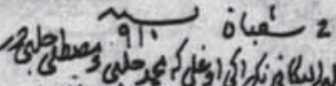
vevil १ٓ

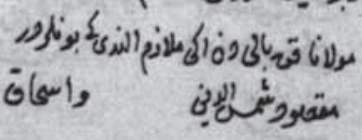

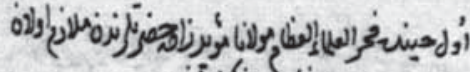
بونروز ذكاوتنز

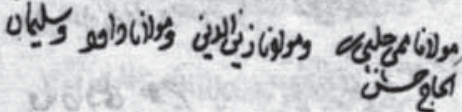

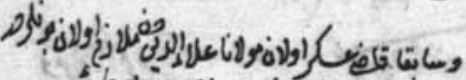
i i

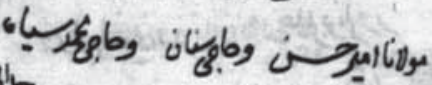
象

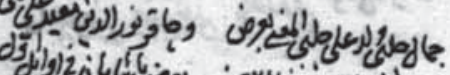

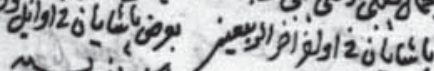

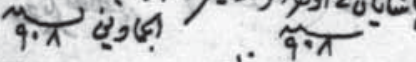

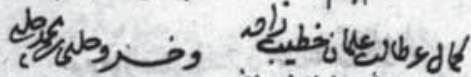

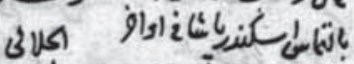
Tत्र

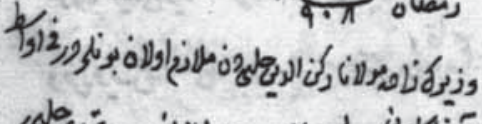
أخزاوناونا

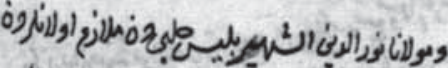

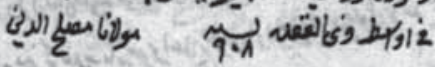

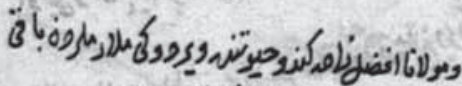
بون بون

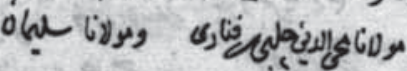
قي 苗 (4)

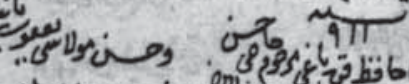

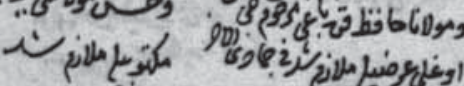

$$
\begin{aligned}
& \text { वेन्त } 2 \\
& \text { वो. }
\end{aligned}
$$


ERCAN ALAN

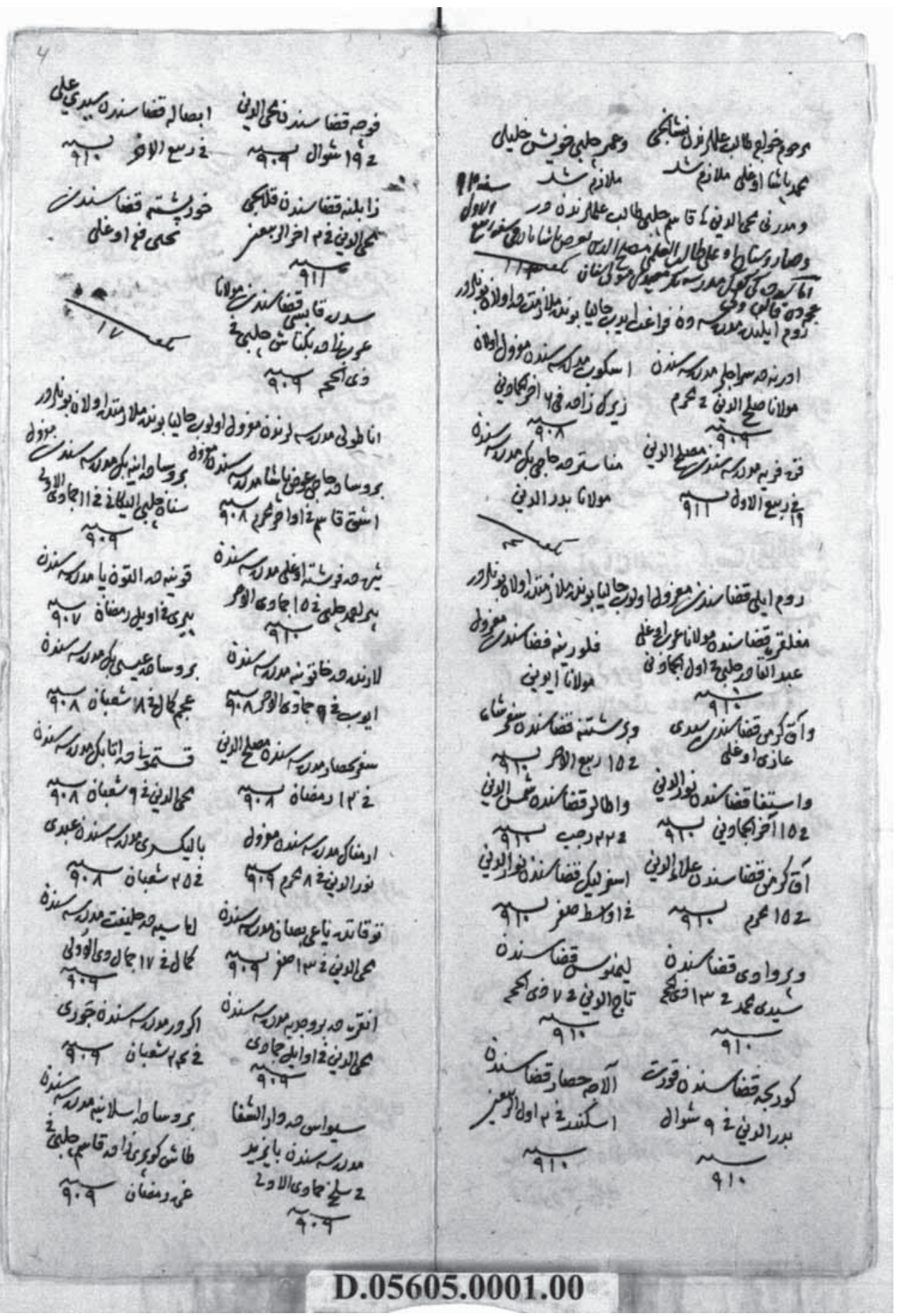

II9 
MÜLÂZEMET SİSTEMİ

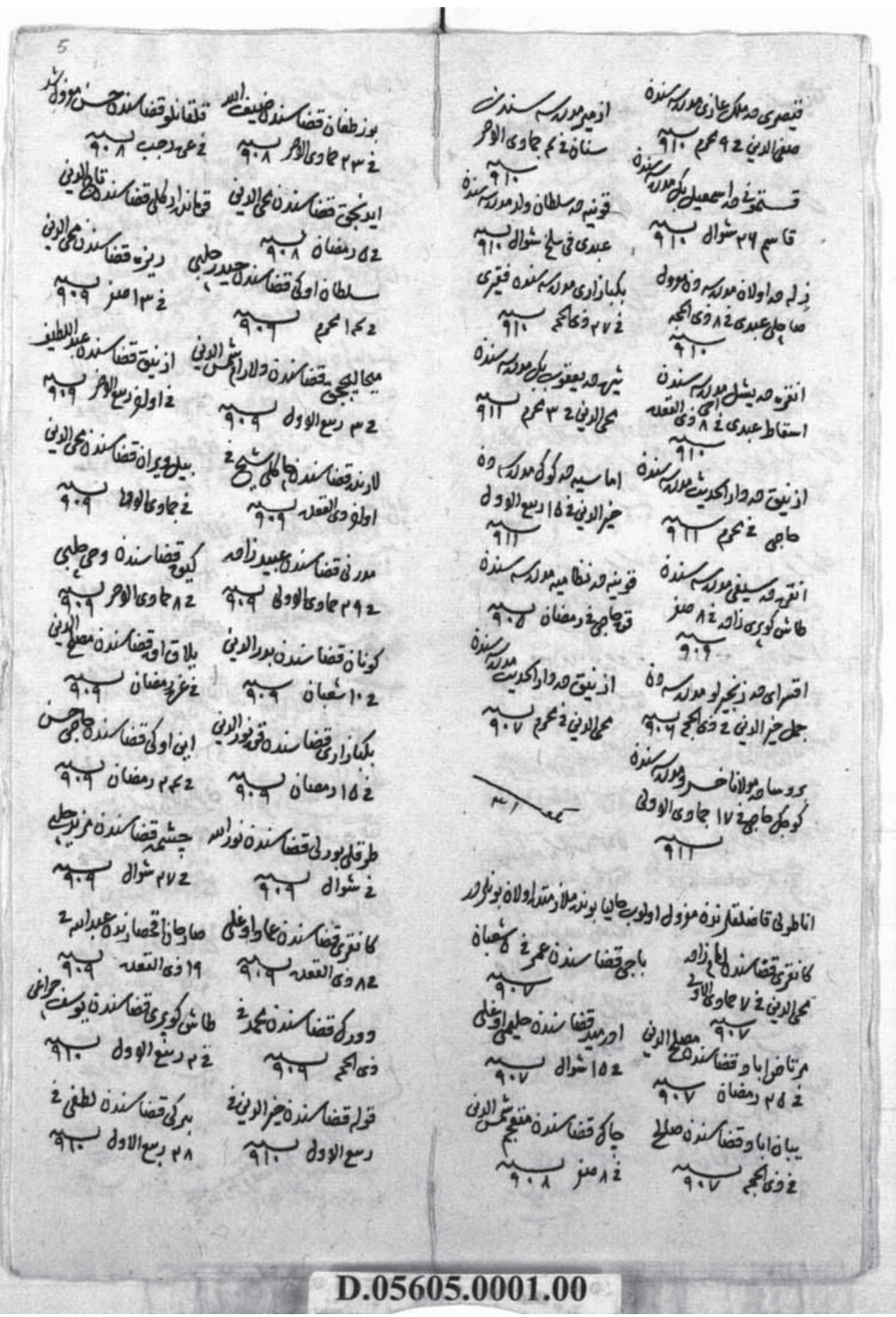

$\mathrm{I} 2 \mathrm{O}$ 
i

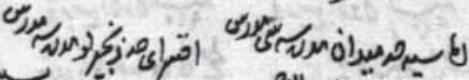
वैद

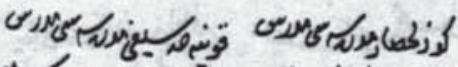

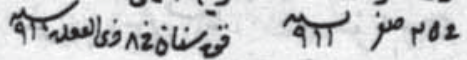

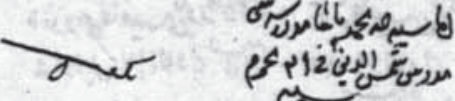

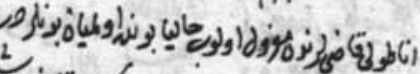
शो

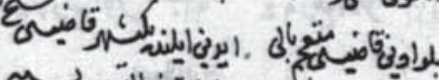

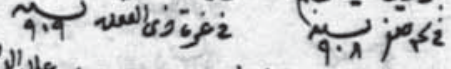

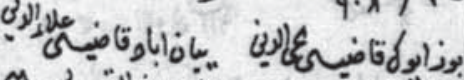

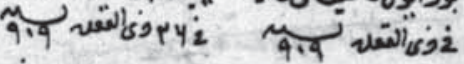

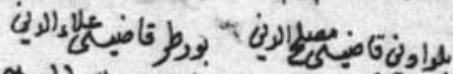

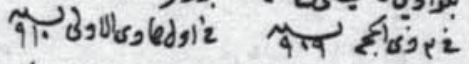

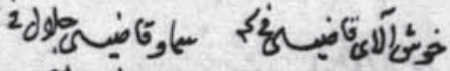

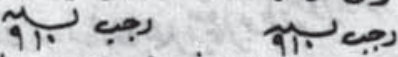

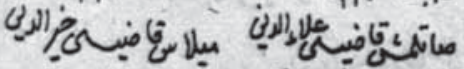

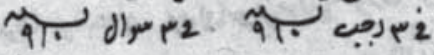

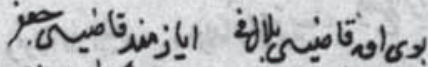

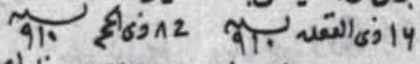

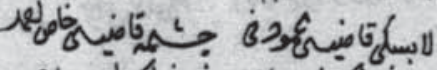
भा. दुgiz भा होजा

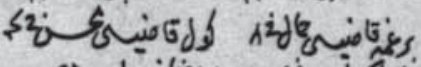

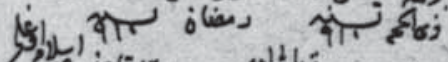

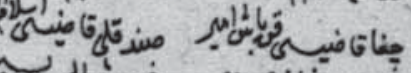

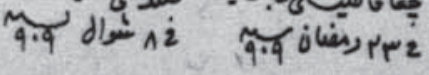

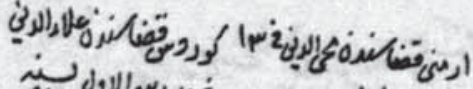

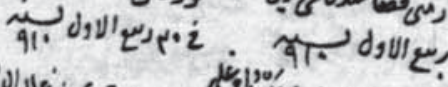

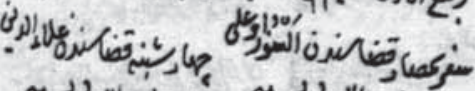

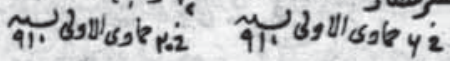

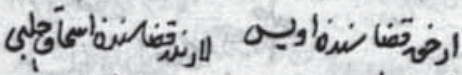
91.

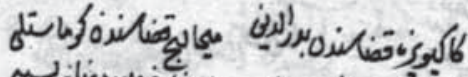
१ب 2

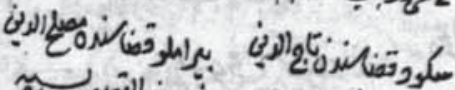

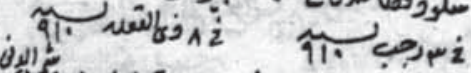

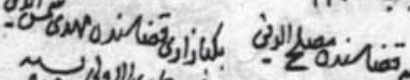
4.4 دون बो.

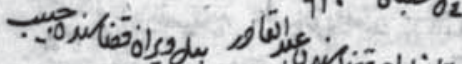

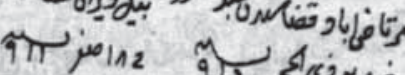
₹oग12

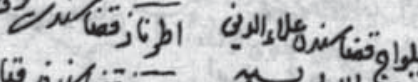

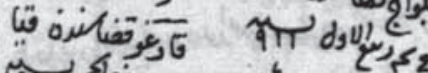

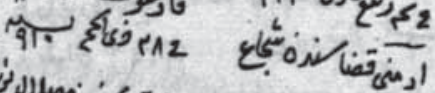

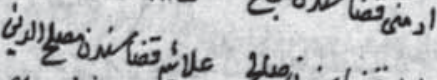
वो

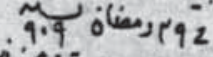

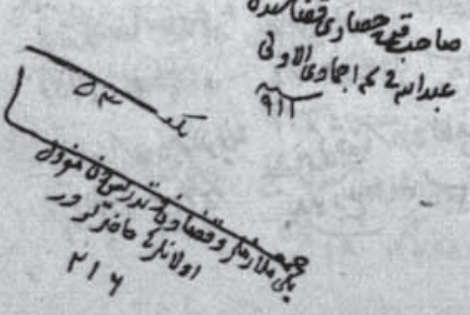




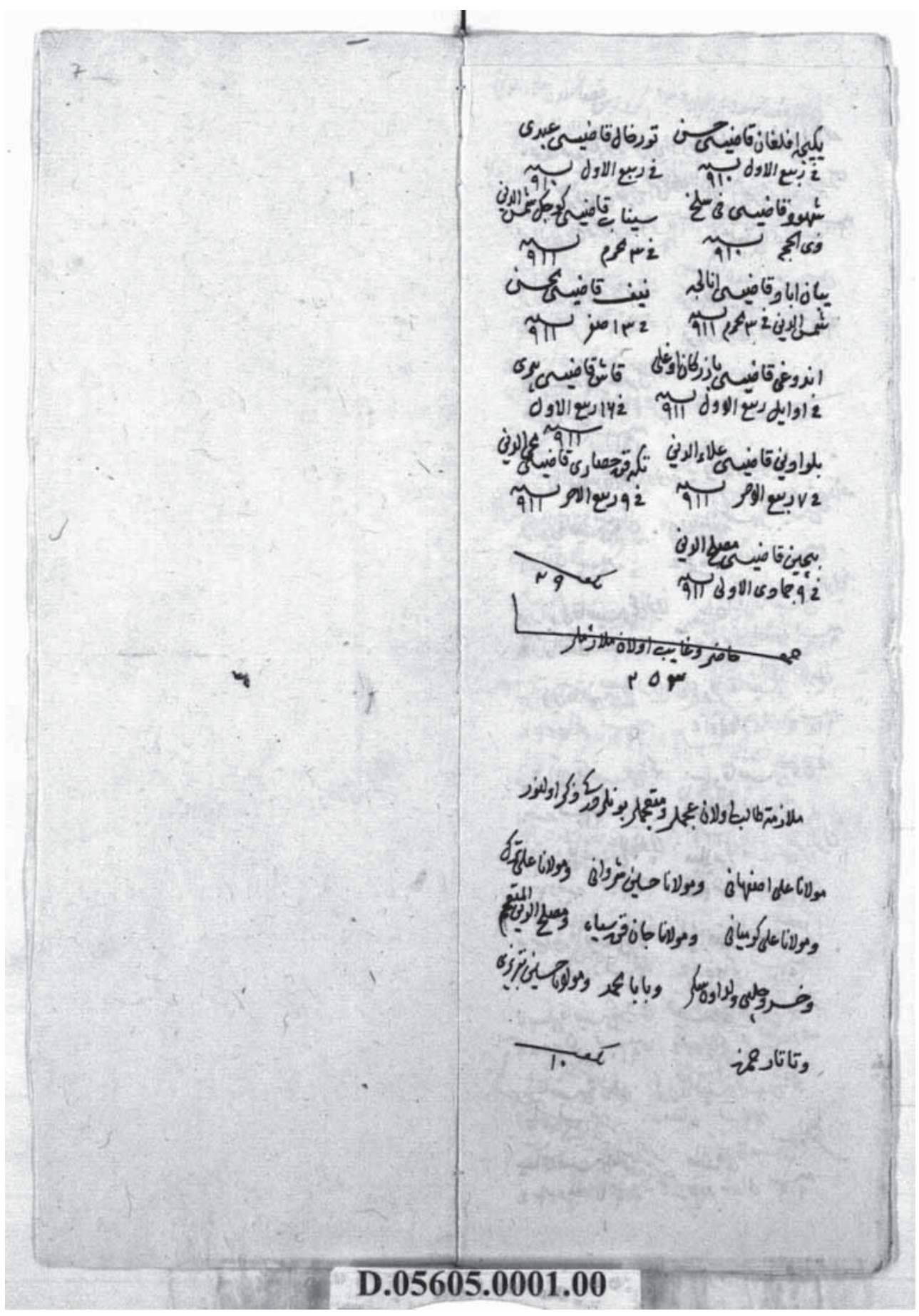




\section{Kaynaklar}

\section{Başbakanlık Osmanlı Arşivi}

Mühimme Defteri No: 73.

\section{Topkapı Sarayı Müzesi Arşivi (TSMA)}

Defter No: 5605/1.

\section{Yayınlanmış Eserler}

Fatih Sultan Mehmed: Atam Dedem Kanunu Kanunnâme-i Âl-i Osman, (haz.) Abdülkadir Özcan, İstanbul: Yitik Hazine Yayınları, 2013.

Gelibolulu Mustafa Âlî: Künhü'l-Ahbâr, C.II, Fatih Sultan Mehmed Devri1451-1481, (haz.) M. Hüdai Şentürk, Ankara: Türk Tarih Kurumu, 2003.

Hezârfen Hüseyin Efendi: Telhîsüll-Beyân fî Kavânîn-i Âl-i Osmân, (haz). Sevim İlgürel, Ankara: Türk Tarih Kurumu, 1998.

Nev'îzâde Atai: Hadâikü’l-Hakâik fî Tekmiletüsş-Şakâik, (haz.) Abdülkadir Özcan, İstanbul: Çağrı Yayınları, 1989.

Yıldırım, Alper: Müstakimzade Süleyman Sadeddin’in Devhatül-Meşayih Osmanlı Şeyhülislamlarının Biyografileri Adlı Eserinin Transkripsiyon ve Değerlendirilmesi, (Yayımlanmamış Yüksek Lisans Tezi), Hatay: Mustafa Kemal Üniversitesi Sosyal Bilimler Enstitüsü, 2014.

\section{Araştırma - İnceleme Eserleri}

Beyazıt, Yasemin: Osmanlı Ilmiyye Tarikinde İstihdam (XVI. Yüzyıl), Ankara: Türk Tarih Kurumu Yayınları, 2014.

Beyazıt, Yasemin: "Osmanlı İlmiye Bürokrasisinde Şeyhülislamlığın Değişen Rolü ve Mülazemet Sistemi (XVI.-XVIII. Yüzyıllar)”, Belleten, LXXIII (2009), 423-441.

Cezar, Mustafa: Osmanlı Tarihinde Levendler, İstanbul: İstanbul Güzel Sanatlar Akademisi Yayınları, 1965.

İnalcık, Halil: “Kazasker Ruznamçe Defterine Göre Kadılık”, Adalet Kitabı, (haz.) Bülent Arı-Selim Aslantaş, Ankara: T.C. Adalet Bakanlığı, 2007, 117-137. 
İpşirli, Mehmet: “Osmanlı Devleti'nde Kazaskerlik (XVII. Yüzyıla kadar)”, Belleten, LXI (1997), 597-699.

İpşirli, Mehmet: "Osmanlı İlmiye Teşkilatında Mülâzemet Sisteminin Önemi ve Rumeli Kazâskeri Mehmet Efendi Zamanına Ait Mülâzemet Kayıtları”, IUUEEF Güney Doğu Avrupa Araştırmaları Dergisi, X-XI (1983), 221-231.

Uzunçarşı1ı, İsmail Hakkı: Osmanlı Devleti’nde İlmiye Teşkilatı, Ankara: Türk Tarih Kurumu, 1998. 